Louisiana State University

LSU Digital Commons

1992

\title{
Attention Deficit-Hyperactivity Disorder Among Mentally Retarded Children.
}

Virginia Elaine Fee

Louisiana State University and Agricultural \& Mechanical College

Follow this and additional works at: https://digitalcommons.Isu.edu/gradschool_disstheses

\section{Recommended Citation}

Fee, Virginia Elaine, "Attention Deficit-Hyperactivity Disorder Among Mentally Retarded Children." (1992). LSU Historical Dissertations and Theses. 5380.

https://digitalcommons.Isu.edu/gradschool_disstheses/5380

This Dissertation is brought to you for free and open access by the Graduate School at LSU Digital Commons. It has been accepted for inclusion in LSU Historical Dissertations and Theses by an authorized administrator of LSU Digital Commons. For more information, please contact gradetd@lsu.edu. 


\section{INFORMATION TO USERS}

This manuscript has been reproduced from the microfilm master. UMI films the text directly from the original or copy submitted. Thus, some thesis and dissertation copies are in typewriter face, while others may be from any type of computer printer.

The quality of this reproduction is dependent upon the quality of the copy submitted. Broken or indistinct print, colored or poor quality illustrations and photographs, print bleedthrough, substandard margins, and improper alignment can adversely affect reproduction.

In the unlikely event that the author did not send UMI a complete manuscript and there are missing pages, these will be noted. Also, if unauthorized copyright material had to be removed, a note will indicate the deletion.

Oversize materials (e.g., maps, drawings, charts) are reproduced by sectioning the original, beginning at the upper left-band corner and continuing from left to right in equal sections with small overlaps. Each original is also photographed in one exposure and is included in reduced form at the back of the book.

Photographs included in the original manuscript have been reproduced xerographically in this copy. Higher quality $6^{\prime \prime} \times 9^{\prime \prime}$ black and white photographic prints are available for any photographs or illustrations appearing in this copy for an additional charge. Contact UMI directly to order.

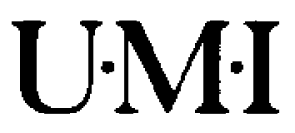

University Microfims International

A Bell \& Howell Information Company

300 North Zeeb Road. Ann Arbor. M1 48106-1346 USA

313:761-4700 B00:521-0600 
Order Number Doseps

Attention Deficit-Hyperactivity Diworder among mentally retarded children

\author{
Foe, Virginis Elaine, Ph.D.
}

Tho Louiaina State Univaraity and Agricultural and Mochanical Col., 1992 


\title{
ATTENTION DEFICIT-HYPERACTIVITY DISORDER \\ AMONG MENTALLY RETARDED CHILDREN
}

\author{
A Dissertation \\ Submitted to the Graduate Faculty of the \\ Louisiana State University and \\ Agricultural and Mechanical College \\ in partial fulfillment of the \\ requirements for the degree of \\ Doctor of Philosophy \\ in
}

The Department of Psychology

\footnotetext{
by

Virginia Elaine Fee

B.A., Hamline University, 1985

M.A. Louisiana State University, 1988 August, 1992
} 


\section{ACKNOWLEDGMENTS}

I would like to thank each of the Professors who have served on my dissertation committee. Doctors Gouvier, Riopelle, Moore, and Coon have provided invaluable help on this project and throughout my graduate studies. As I leave L.S.U., I am sure their example will remain with me for the rest of my career.

A very, very special thanks is directed toward Dr. Matson who has provided me immeasurable professional and personal advice. In addition to the solid background in psychology Dr. Matson has provided, his patience and encouragement are fondly acknowledged and will always be remembered.

This project would not have been possible without the help of many principals and the forty participating school teachers. Mr. Wyble, Principal at Port Allen Elementary, deserves special acknowledgement for his support.

Finally, I would like to thank the many friends and relatives who have helped me in accomplishing my goals.

This dissertation is dedicated to my loving mother, Evelyn N. Fee, and to the memory of my father, the Reverend David A. Fee, Ph.D.

"And when the Earth shall claim your limbs, Then, shall you truly dance...."

$$
\begin{array}{r}
\text { Virginia Elaine Fee } \\
\text { August, } 1992
\end{array}
$$


TABLE OF CONTENTS

page

ACKNOWLEDGEMENTS .................... 11

LIST OF TABLES......................

LIST OF FIGURES $\ldots \ldots \ldots \ldots \ldots \ldots \ldots \ldots$

ABSTRACT ...........................

INTRODUCTION. ........................

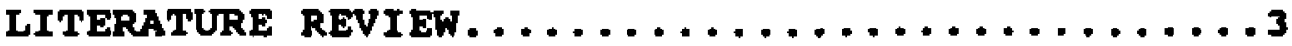

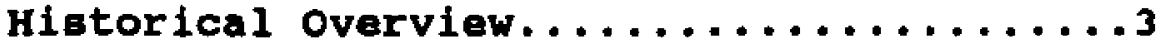

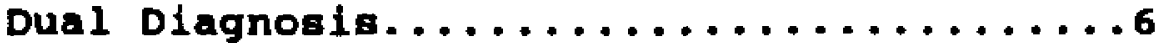

Theories of Paychopathology in

Mentally Retarded children.........10

Definitions of Mental Retardation.......12

Definitions of Attention Deficit-

Hyperactivity Disorder............14

Incidence of AD-HD..............19

Etiology .................... 20

AD-HD in Developmentally Disabled

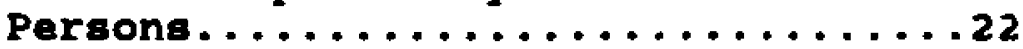

Assessment of AD-HD................ 25

AD-HD rating scales.............25

observational coding systems......28

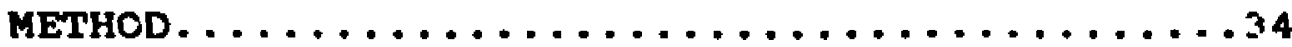

subjects and setting.................. 34

Mentally retarded group.......... 34

Mentally retarded AD-HD group......34

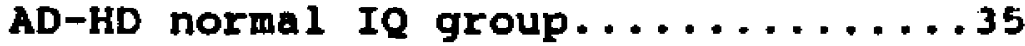

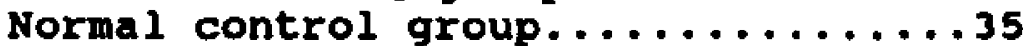

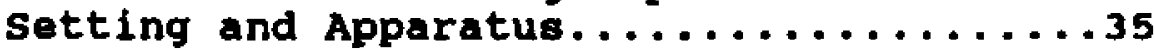

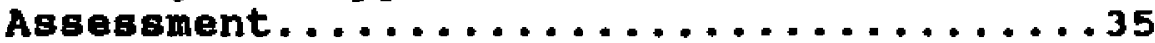

Demographic information form......35

Intelifgence estimation.........36

DSM-III-R checklist. . . . . . . . . 36

Conners" Teacher Rating Scale-39

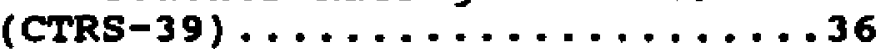

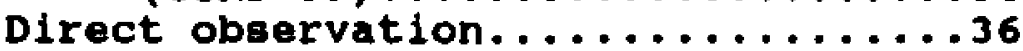

REsuLts. ...........................41

Reliability of observations.........44

Demographic Characteristics..........41 
TABLE OF CONTENTS

(CONTINUED)

Reliability of Diagnosis...........41

Differences Between Groups...........43

observations...................46

Differential validity.............46

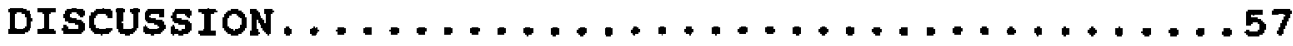

SUMMARY . . . . . . . . . . . . . . . . . . 64

REFERENCES . . . . . . . . . . . . . . . . 66

APPENDIX A CONNERS FACTOR $1 \ldots \ldots \ldots \ldots \ldots$

APPENDIX B CONNERS FACTOR $2 \ldots \ldots \ldots \ldots$

APPENDIX $\subset$ CONNERS FACTOR $3 \ldots \ldots \ldots . \ldots . \ldots . \ldots 7$

APPENDIX D CONNERS FACTOR $4 \ldots \ldots \ldots . \ldots . \ldots . \ldots 89$

APPENDIX E CONNERS FACTOR 5............91

APPENDIX F CONNERS FACTOR $6 \ldots \ldots \ldots . \ldots . \ldots 9$

APPENDIX G CONNERS HYPERACTIVITY INDEX......95

APPENDIX H IOWA CONNERS INATTENTION/

OVERACTIVITY SUBSCALE. . . . . . . . . . . 97

APPENDIX I IOWA CONNERS AGGRESSION/

OPPOSITIONAL-DEFIANT SUBSCALE. . . . . . . .99

APPENDIX J CONSENT FORM............... 101

APPENDIX K DEMOGRAPHIC INFORMATION SHEET....103

APPENDIX L BEHAVIOR CHECKLIST. . . . . . . . 105

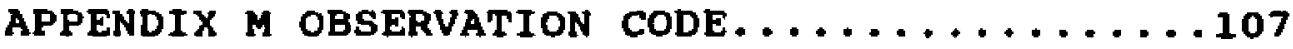

vita. ................................. 
Table

Page

1. Age, IQ, Race, and Clase Placement.......42

2. Means and standard Deviations for the Conners Factors and IOWA Scales by Group. . . . . . . . . . . . . . . . 47

3. Means and standard Deviations for observation Total Score by Group.....49

4. Intercorrelations of Teacher Ratings on the Conners Factors and IOWA scales within the Mentally Retarded Groups....51

5. Intercorrelations of Teacher Ratings on the Conners Factors and IOWA Scales Within the Normal Io Groups........52

6. Percentage of students Above the Cut-off on the Hyperactivity Index, IOWA-IO Scale, IOWA-A Scale, and both IOWA

Scales........................56 


\section{LIST OF FIGURES}

Figure

Page

1. Mean Scores on the Connerg' Hyperactivity Factor, Conduct Problem Factor, Hyperactivity Index, and IOWA-Io scale for the mentally retarded, mentally retarded $A D-H D, A D-H D$, and normal

groups..........................44

2. Mean Scores on the Conners' Emotional/ overindulgent and Anxious/Paseive Factors for the mentally retarded, mentally retarded $A D-H D, A D-H D$, and normal groups...................45

3. Mean Scores on the Connerg' Daydream/ Attention Problem Factor, IOWA-A Scale and Asocial Factor for the mentally retarded, mentally retarded AD-HD, AD-HD, and normal groups...........48

4. Mean observation total scores for the mentally retarded, mentally retarded $A D-H D, A D-H D$, and normal

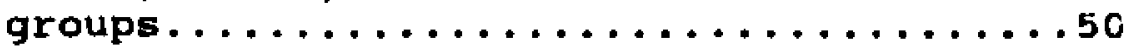




\begin{abstract}
Teachers completed the CTRS-39 on 100 boys assigned to one of four groups based on IQ and scores on a DSM-III-R checklist of the symptoms for Attention DeficitHyperactivity Disorder (AD-HD) . The groups included a normal control group, children with AD-HD, mentally retarded children, and mentally retarded children with ADHD. There were no significant differences between the ADHD group and the mentally retarded AD-HD group on all but one of the conners' Factors and no significant differences on the IOWA Conners' Scales that were extracted from the CTRS-39. Mentally retarded children in general were found to be more anxious than their normal peers, whereas AD-HD children were rated higher than the other groups on the Asocial factor. Attention problems were significantly correlated with conduct and hyperactivity factors for the normal IQ children but not for the mentally retarded children. Implications of these data and CTRS scoring system recommendations for mentally retarded children are discussed.
\end{abstract}




\section{INTRODUCTION}

Mentally retarded children have been traditionally overlooked in the child psychopathology literature (Matson \& Frame, 1985). Despite the fact that these children are often challenging to educate and parent, few studies have examined behavior disorders within this group, and most current psychopathology texts do not cover the topic.

Attention Deficit-Hyperactivity Disorder is the most common reason for referral to child mental health clinics (Whalen, 1989). Data is currently not available on the proportion of children who are referred for this reason and who are concomittantly mentally retarded. The premise of this paper is that attention deficits and overactivity are commonly encountered behavior problems in children of subnormal intelligence. To address this question, one hundred school-age boys were evaluated using teacher ratings and direct observations.

In this paper, a comprehensive approach to the study of Attention Deficit-Hyperactivity Disorder is presented. First, historical approaches to treating mentaliy retarded individuals is presented. Next, dual diagnosis and previous research on behavior disorders in mentally retarded children is discussed, followed by an overview of theories on the development of psychological problems in mentally retarded persons. Mental retardation and Attention Deficit-Hyperactivity Disorder are defined and 
research on these disorders co-occurring is reviewed. Additionally, methods for assessing Attention DeficitHyperactivity Disorder are described.

The majority of the paper describes the research methods, subject characteristics, and the specific results obtained in the study. Finally, conclusions and future directions are summarized. 


\section{LITERATURE REVIEW}

\section{Historical Overview}

Mentally retarded children comprise the majority of children receiving special education services (Blake, 1981). Although currently all children have the right to a free and appropriate education, this has not always been the case (Herr, 1983). The complexities of educating and treating these children have only been addressed recently.

Prior to the nineteenth century, mental retardation and psychopathology were often confused. Both sets of individuals were viewed as "possessed" or the result of parental sins. Rather than habilitation, treatment generally consisted of incarceration due to burdens on the family and community. Diagnostically, mental retardation was determined, largely on arbitrary criteria, by a jury of 12 men and resulted in the loss of all property and future inheritance. Thus, the mentally retarded person was often jalled or left to perish on his or her own (Herr, 1983).

As early as 1697, Daniel Defoe in England called for more humane treatment and residential facilities for mentally retarded individuals. Interestingly, Defoe's idea was for authors with a "Portion of Understanding Extraordinary" to pay a "Tax Upon Learning" to provide financial support for mentally retarded persons. Although 
his ideas were ignored for the next 150 years, custodial care for mentally retarded persons eventually came into being in 1847 with the Park House in Highgate, London (Herr, 1983).

The situation in the United states was not substantially better for mentally retarded persons. However, in France, Edward seguin founded the first residential school for mentally retarded individuals in 1838 (Herr, 1983). He authored the book, The Moral Treatment, Hygiene, and Education of Idiots and other Backward Children (Seguin, 1846) and later initiated training schools in the United states (Herr, 1983). Dorothea Dix was also active during this time, advocating treatment of mentally retarded persons. A statement from her in 1848 indicated that she had seen more than "nine thousand idiots, epileptics, and insane... destitute of appropriate care and protection...bound with galling chains, bowed beneath fetters and heavy iron balls" (Dix, 1848). She called for state asylums that would separate mentally retarded persons from the insane (Herr, 1983). Only one year later, Dr. A. Brigham suggested that many of New York's 1,600 mentally retarded individuals could be habilitated to the point of employment and self-support (Brigham, 1845).

After the first institution separating mentally retarded persons from mentally individuals in 1848 , 
education of mentally retarded persons became a focus. However, this activity was primarily rhetorical discussion. It is only in recent years that habilitation of mentaliy retarded people, including education and training in adaptive and communication skills, has been attempted (Herr, 1983).

For the next 100 years, treatment of mentally retarded persons was thwarted by schools of thought such as the eugenics and segregationist movements (Davies, 1930; Fernald, 1915). These philosophies produced new but inhumane rationales for the permanent separation of mentaliy retarded individuals from the rest of society. During the $1950^{\prime} \mathrm{s}$ and $1960^{\prime} \mathrm{s}$, however, dramatic changes began to emerge. Efforts to integrate mentally retarded persons into community life were initiated (Herr, 1983). During the Kennedy administration and throughout the civil Rights Movement, education of the handicapped and prevention of mental retardation were advocated (Matson, $1983)$.

Two landmark cases, Miller $v$. Board of Education and Pennsylvania Association for Retarded Children (PARC) $v$. Pennsylvania, influenced the enactment of the Education for All Handicapped Children Act (PL-94-142) in the early 1970's. This act specified that all children are entitled to a free and appropriate education. 
The concepts of "mainstreaming" and "the least restrictive environment" are central to the act's premise. Mainstreaming refers to the integration of handicapped children with nonhandicapped peers. Providing services in the least restrictive environment means that, whenever possible, handicapped children should not be segregated from the rest of the community. Mainstreaming efforts have included the opportunity for special education students to attend classes or activities with nonhandicapped peers on regular school campuses (Herr, 1983).

However, mentally retarded individuals sometimes display behavior problems or psychological disorders that may prevent or limit mainstreaming efforts. Recent research suggests that mentally retarded children are more likely to exhibit deviant behavior than are children in the general population (Jacobsen, 1982). In the next section, psychological problems of mentally retarded persons and diagnostic issues are addressed. pual Diagnosis

In the past 15 years, psychological disorders occurring in mentally retarded individuals has become an area of study (Rojahn \& Burkhart, 1988). Previously, psychological disorders exhibited by mentally retarded individuals tended to be ignored by the research and clinical community. It was most common for mentally 
retarded persons with coexisting psychological disorders to receive either a diagnosis of mental retardation or mental disorder, but rarely both (Matson \& Frame, 1985). The finding that emotional or behavioral disturbances are attributed to mental retardation itself rather than being viewed as an additional disturbance has been called "diagnostic overshadowing" (Reiss, Levitan, s syzko, 1982). For instance, Reiss, et. al. (1982) presented psychiatrists with scenarios describing persons with mental retardation and psychological disorders and those with psychological disorders alone. These psychiatrists were less likely to assign a psychological diagnosis when the person showed evidence of mental retardation.

Recent efforts have shown that psychological problems are actually more common among mentally retarded persons than persons of normal intelligence (Rutter, 1971; Rutter, Tizard, Yule, Graham, \& Whitmore, 1976). Rutter and associates (1971; 1976) studied children living off the coast of England and found that 30 of the mentally retarded children had an emotional disturbance. When compared to rates among the child population, these rates are 5 to 6 times higher (Frame Matson, 1985).

In another investigation, Jacobsen (1982) studied 30,578 mentally retarded children, adolescents, and adults. His findings were that $9.8 \%$ of the population displayed coexisting psychopathology. Although this rate 
1s much lower than Rutter's (1976; 1971), it should be noted that Jacobsen (1982) studied only the most severe forms of disorder and rates were determined on mentally retarded persons referred to mental health facilities (Matson frame, 1985). In addition, Rutter (1976; 1971) studied only mentally retarded children, whereas Jacobsen (1982) also studied adults and adolescents.

In addition to the high rates of psychopathology found among persons with mental retardation, Matson and Frame (1985) noted that several types of psychological problems have been observed within this population. For instance, Kelly, Koch, and Buegel (1976) described bipolar depression in a 15-year-old mentally retarded person. others have noted depressive disorders in other age groups of mentally retarded individuals (Kazdin, Matson, \& Senatore, 1983). Moreover, phobias and fears have been observed in mentally retarded children (Matson, 1981 ). Using the Personality Inventory for Children (PIC), Dekrey and Ehly (1981) found that $12.5 \%$ of their educably mentally retarded sample had both intellectual impairment and internalizing symptoms (e.g., depression, withdrawal, or anxiety). These mentally retarded children were often found to be more anxious, depressed, and less welladjusted than were their peers of normal intelligence.

Cullinan, Epstein, and Dembinski (1979) by using the Behavior Problem Checklist (BPC; Quay \& Peterson, 1975) 
found that mentally retarded elementary school boys displayed more conduct, anxiety/withdrawal, and attention deficit disorder than average. Factor analysis of BPC's from 259 mentally retarded adolescents showed conduct disorder, socialized delinquency, anxiety/withdrawal, depression, and attention deficit disorder. Of note, depression and attention deficit factors were not found among the adolescents of normal intellectual functioning (Matson, Epstein, \& Cullinan, 1984). Although there could be several reasons for this finding, perhaps mentally retarded children retain symptoms longer.

In England, others studied a group of 200 mentally retarded children from birth to early adulthood. Richardson, Katz, Koller, McLaren, and Rubenstein (1979) showed that one-fifth of their sample experienced aggression problems and one-fourth exhibited problems of an internalizing nature, such as depression or anxiety. In sum, almost half of the mentaliy retarded children displayed either aggression or internalizing behavior before reaching adulthood (Matson \& Frame, 1985).

In the 1982 study by Jacobsen, aggression, selfinjury, hyperactivity, and affect problems were the most common psychological disturbances coexisting with mental retardation. A few investigators have specifically examined $A D-H D$ in developmentally disabled children. Numerous researchers have reported children with mental 
retardation, Tourette's syndrome, and hearing impairments who also display characteristics of AD-HD (Alvarez * Londono, 1982; Chess Fernandez, 1981; Epstein, Cullinan, c Gadow, 1986; Fejes \& Prieto, 1987; Fisher, Burd, Kuna, * Berg, 1985; Hogue \& Biederman, 1986; Litrownik, Whit, McInnis, Licht, 1984). In a later section, results of studies investigating Attention Deficit-Hyperactivity Disorder among mentally retarded children will be reviewed.

It appears that psychological disorders do occur in mentally retarded children. In the following section, theories designed to explain the development of psychological disorders in mentally retarded children is presented.

Theories of Psychopathology in Mentally Retarded children

In their 1985 book, Matson and Frame gummarized theories on the development and maintenance of psychological disorders among mentally retarded chilaren. They reviewed three models of psychopathology.

(1.) The organic model emphasizes physiological, biological, and genetic factors as potential causes of psychological disturbance. In the most serious forms of psychopathology, such as autism and self-injury, this approach has dominated (Matson \& Frame, 1985). For instance, chemical agents such as pemoline and caffeine have been studied in animals and appear to create self- 
injury (Genovese, Napoli, Bolego-Sonta, 1969; Peters, 1967). Moreover, biochemical changes may be associated with schizophrenia (Freedman, Kaplan, \& Sadock, 1975).

(2.) Recently, developmental approaches to psychopathology among mentally retarded persons have had great impact in the field (zigler, Balla, \& Hodapp, 1984). Highlighting this influence, the term "developmental disabilities" is currently used to describe individuals afflicted with a variety of handicaps since it is assumed that mentally retarded children develop at a similar but slower timetable (Matson \&rame, 1985).

The developmental approach to childhood psychopathology, where it is known that some behaviors occur most frequently among certain age groups, is central to the developmental approach to psychopathology in mentally retarded children. For example, tantrums in young children are fairly common. However, in older children and adults, this behavior would be considered abnormal. When applied to mentally retarded persons, developmental timetables are thought to differ (Matson a Frame, 1985). The emergence and disappearance of behavior problems may also vary from the norm because of the degree to which a person is intellectually impaired. Thus, a profoundly mentally retarded person would lag further behind than a mildly mentally retarded individual. 
(3.) A third model for the development of psychopathology in mentally retarded persons concerns the effect of environmental variables. Social learning, operant, classical conditioning, and psychodynamic models are included within this general category (Matson Barrett, 1982). As applied to mentally retarded children, the operant and social learning models have been used most often (Matson \& Frame, 1985).

The study of psychopathology among mentally retarded persons is a growing area of research. In general, it appears that most work thus far has focused on determining incidence rates and on generating theories of development.

This study is an attempt to examine a secific disorder, Attention Deficit-Hyperactivity Disorder, among mentally retarded children. Prior to examining the problem of Attention Deficit-Hyperactivity visorder, a brief review of mental retardation and its definitions is in order.

Definitions of Mental Retardation

In defining mental retardation, several systems of classification have been used historically. currently, the two major oystems in the United states are provided by the American Association on Mental Retardation (AAMR), previously the American Association on Mental Deficiency (AAMD), and the Diagnostic and statistical Manual-III-R 
(DSM-III-R) of the American Psychiatric Association $(1987)$.

The AAM classification system is most popular and uses a three criteria approach. First, mental retardation must be present before the age of 18 . Second, the individual must score two or more standard deviations below the mean on an individually administered intelligence test. Finally, the person must show adaptive behavior deficits characteristic of mental retardation. If the person fails on any of the criteria, (s)he is not considered mentally retarded (Grossman, 1983). This system was developed due to criticism of using scores of intelligence alone (Matson Frame, 1985). However, some believe the sole measure of mental retardation should be the standardized intelligence test, since measures of adaptive functioning have not been especially helpful in determining intellectual functioning (zigler, et. al., $1984)$.

DSM-III-R (American Psychiatric Association, 1987) adopted the AAMR criteria. However, this system allows use of the standard error of measurement when diagnosing mental retardation. The manual states, "since any measurement is fallible, an IQ score is generally thought to involve an error of measurement of approximately five points; hence, an IQ of 70 is considered to represent a band or zone of 65 to $75 . "$ (DSM-III-R, 1987, p. 28). 
Therefore, persons with IQ scores slightly above 70 may be diagnosed if severe deficits in adaptive behavior are also present.

Mental retardation is divided into four major groupings. Mildly retarded persons (IQ of 55 to 70) make up 90 to 96 of the mentally retarded population. They can generally speak in sentences, follow directions, walk, and sometimes learn to read. Moderately retarded individuals are usually unable to read or write. They often have poorly developed fine motor akills and have difficulty following instructions. Persons with severe mental retardation may have problems with receptive and expressive language. Profoundly mentally retarded individuals usually require assistance with dressing, toileting, and feeding (Matson Frame, 1985).

As already established, psychological disorders occur in mentally retarded persons at rates comparable to or above rates occurring in the general population. 'The next section describes, a specific disorder, Attention DeficitHyperactivity Disorder, a common problem of childhood. Definitions of Attention Deficit-Hyperactivity Disorder

Attention Deficit-Hyperactivity Disorder (AD-HD) is one of the most extensively studied disorders of childhood yet one of the most controversial (Fee Matson, in press). Defining $A D-H D$ continues to be one of the most pressing matters in child psychopathology research, since 
our conceptualization of AD-HD has changed dramatically over the years.

At first an emphasis was placed exclusively on brain damage as the cause of hyperactivity (still, 1902). However, brain damage could not be demonstrated in most hyperactive children (Fine, 1977; Safer \& Allen, 1976). Moreover, among those hyperactive children who did evince unusual findings no consistent pattern of neurological test results were found (Werry, 1968).

Next, authors focused on more behavioral definitions of the problem, emphasizing neurological soft signs, such as poor balance, impaired fine motor coordination, and reflex asymmetries. Shortly, the term "minimal brain dysfunction" was coined to describe children with hyperactivity (Kessler, 1980). However, objections were raised concerning the inference of brain damage from behavioral symptoms alone, and studies showed that many hyperactive children displayed no soft signs (Bax * Mackeith, 1963; Casey, 1977).

The question then became one of overactivity, attention deficits, or both as the primary problem (Chess, 1960; Childers, 1935; Douglas, 1972; Levin, 1938; Werry sprague, 1970). This is still an issue (Whalen, 1989). Currently, we view AD-HD as a multifaceted problem, having diverse etiologic and maintaining factors (Fee Matson, in press). 
The changing definition of $A D-H D$ is also reflected in editions of the Diagnostic and statistical Manuals of the American Psychiatric Association (American Psychiatric Association, $1968 ; 1980 ; 1987$ ). The disorder was first recognized in DSM-III as "Hyperkinetic Reaction of Childhood" emphasizing excessive motor activity (American Paychiatric Association, 1968). Next, DSM-III focused on the attentional component and provided the diagnoses of Attention Deficit Disorder with Hyperactivity (ADD-H) or Attention Deficit Disorder without Hyperactivity (ADD) (American Psychiatric Association, 1980).

Attention deficits and overactivity have been recombined in DSM-III-R under the label Attention DeficitHyperactivity Disorder (American Psychiatric Association, 1987). Whether motoric or attention components are essential for the diagnosis is still unresolved. Currently, DSM-III-R (American Psychiatric Association, 1987) uses inattention, impulsivity, and hyperactivity as core symptoms, but allows emphasis on any of the three. However, there may be diagnostic validity in the categories of ADD and ADD-H previously specified in DSMIII (American Psychiatric Association, 1980). For example, Brown (1985) found that teachers' could discriminate these two categories and that they viewed those children with hyperactivity in addition to attentional problems as more difficult to manage. 
Other diagnostic controversies abound. First, there is a question of the syndrome's very existence. Whether AD-HD is a cluster of behaviors separate from conduct disorder has been subject to extensive validation. Many feel further investigation is necessary before this issue can be resolved (Caperaa, Cote, Thivierge, 1985; Holborow Berry, 1985; Luk, 1985; Quay, Routh, \& Shapiro, 1987). For instance, when the effects of age, sex, and IQ were controlled, Werry, Elkind, and Reeves (1987) found few differences between children with DSM-III diagnoses of ADD-H, anxiety problems, and ADD-H plus conduct disorder. others contend that $A D-H D$ and conduct disorder are independent syndromes but that a third category exists where $A D-H D$ and conduct disorder co-occur (Hinshaw, 1987; McGee, Williams, \& Silva, 1985; Reeves, Werry, Elkind, * Zametkin, 1987; Shapiro Garfinkel, 1986; Stein, O'Donnell, 1985; Walker, Lahey, Hynd, \& Frame, 1987; Weiss, 1985; Werry, Reeves, \& Elkind, 1987). In a few investigations, the comorbid group, children with AD-HD and conduct disorder, displayed greater soclal dysfunction (Reeves, et. al., 1987) and family problems (August \& Stewart, 1984 ; Lahey, Piacentini, McBurnett, stone, 1988; Reeves, et. al., 1987). Interestingly, walker, et. al. (1985) concluded that the children with AD-HD and conduct disorder exhibited more aggression and severe 
antisocial behavior than children with conduct disorder alone.

Another area of diagnostic confusion concerns the independence of AD-HD and learning disabilities. Much less work has been done in this area. In one recent investigation, Dalby (1985) showed that children with developmental reading disorders exhibited greater academic problems than children with ADD. The ADD group was rated significantly more hyperactive than controls were, whereas the reading disordered children were not. Dalby (1985) therefore concluded that $A D D$ and developmental reading disorder constitute separate entities. However, there has been a longstanding suggestion that these disorders constitute separate but overlapping categories similar to that observed with $A D-H D$ and conduct disorder (Conners, 1976; Wender, 1976).

A final area of controversy concerns the nature of the disorder, whether it is situation-specific or situation-independent since a common finding among $A D-H D$ children is that the severity of the problem differs from environment to environment (Barkley, 1989). It has been repeatedly noted that these children show fewer behavior problems in unstructured free-play settings compared to more restrictive environments such as the learning situation (Barkley, 1985; Jacob, O'Leary, \& Rosenblad, 1978; Luk, 1985; Routh schroeder, 1976; Whalen, collins, 
Henker, Alkus, Adams, Stapp, 1978). Barkley (1989) reviewed findings and suggested that the apparent attentional deficit in AD-HD may actually be a motivational one, since the child's behavior worsens with increased environmental familiarity, improves when immediate consequences are provided, and when instructions are given frequently. Establishing the core problem in $A D-H D$ may be the most important problem facing $A D-H D$ researchers in the near future.

Incidence of $A D-H D$. The problem of $A D-H D$ is pervasive in that 2 to 5 of all children are affilicted (Barkley, 1982). According to Whalen (1989), epidemiological studies in North America show that 38 to 158 of school-age children can be diagnosed as "hyperactive," with some studies showing rates of up to 248 (Offord, et a1., 1987; Sandoval, Lambert, sassone, 1980; Satin, Ninsberg, Monetti, Sverd, 6 Foss, 1985; Trites, 1979). Studies based on community and clinic samples consistently show AD-HD as the most common childhood problem (Whalell, 1989). Up to 50\% of children referred for clinical problems are likely to be diagnosed AD-HD (stewart, Cummings, Singer, \& Debois, 1981) .

Another consistent finding is that AD-HD occurs more frequently in boys (Whalen, 1989). Three to 6 males are commonly reported for each female diagnosed with AD-HD. And it has been suggested that AD-HD occurs in 5 t to 24 t 
of boys and $2 t$ to $13 \%$ of girls. (Anderson, williams, McGee, Silva, 1987; Berry, Shaywitz, \& Shaywitz, 1985; Eichsleder, 1985; Holborow, Berry, 1986).

Etiology. As previously mentioned, neurological soft signs and minor physical anomalies were previously thought to differentiate AD-HD children from normals. However, findings were not consistent and often unconfirmed (Ferguson Rapoport, 1983; Shaffer et al., 1985). Whalen (1989) summarized more current etiological theories of ADHD. Genetic, neurotransmitter, and environmental theories have been presented.

concerning genetic theories, it appears that a large number of parents of AD-HD children showed similar symptoms during childhood; $A D-H D$ is often found among siblings; and full siblings are more likely than halfsiblings to display the behavior (Morrison s stewart, 1974; Nichols Chen, 1981; Pauls, Shaywitz, Kramer, Shaywitz, Cohen, 1983; Safer, 1973; Welner, Welner. stewart, Palkes, wish, 1977). Twin studies show a higher concordance rate for activity level in monozygotic versus dizygotic twins (Buss Plomin, 1975; Matheny \& Dolan, 1980; Torgersen kringlen, 1978). Unfortunately, studies of twins reared apart have yet to be performed (Whalen, 1989).

overarousability and underarousability theories have been suggested. Currently, evidence suggests children 
with an underarousability problem as the most common subtype of AD-HD, although results are far from definitive (Whalen, 1989). According to whalen (1989), deficits in the catecholamines dopamine and norepinephrine have been suggested, but the evidence is contradictory (zametkin Rapoport, 1986; Shaywitz, Shaywitz, Cohen, Young, 1983). However, methylphenidate and dextroamphetamine, the two most effective medications for AD-HD, show differing effects on neurotransmitter metabolites (2ametkin, Karoum, Linnoila, Rapoport, Brown, Chuang, wyatt, 1985). Whalen (1989) pointed out the possible effect of stress on neurotransmitter levels and suggested that stress may play a role when neurotransmitter differences are found in ADHD children.

Environmental theories include possible toxins to the body and psychosocial influences. Lead, sugar, food preservatives, and maternal smoking have been suggested as environmental causes of AD-HD. Of these, both lead and maternal smoking show some possible linkage (Denson, Nanson, \& McWatters, 1975; Nichols Chen, 1981). Dietary factors such as sugar and food dyes have largely been abandoned as causitive agents in AD-HD (Whalen, 1989). According to whalen (1989), evidence showing a relation between $A D-H D$ and low socioeconomic status (SES) is conflicting (McGee, williams, \& Silva, 1984; Paternite * Loney, 1980; Schachar, Rutter \& Smith, 1981) . However, 
variables associated with low ses, such as divorce, low educational and vocational status, may contribute to the development of AD-HD. However, family problems tend to be associated with conduct disorder rather than AD-HD (Whalen, 1989). Conversely, results of a 10-year followup study concluded that for low SES AD-HD children, family stability rather than perinatal stress accounted for substantial variance (Werner et al., 1971).

In sum, etiological studies of AD-HD have failed to find a single agent responsible for the development of $A D-$ HD symptoms. There appears to be support for inherited and other biological influences and also environmental causes. However, years of research will probably be necessary before these issues are resolved. Next, the focus of discussion shifts to the co-occurrence of $A D-H D$ and mental retardation.

\section{AD-HD in Developmentally Disabled Persons}

In recent years, a few investigators have provided some hints that $A D-H D$ in developmentally disabled persons may be important. In addition to suggesting that the disorder exists in mentally retarded children, a few studies have examined treatment of $A D-H D$ in mentally retarded children. For instance, CNS stimulants have been examined. Using the double-blind placebo method, several investigators have failed to find effects (Alexandris 6 Lunde11, 1968; Aman, 1982; Anton \& Greer, 1969; Bel1 \& 
Zubeck, 1961; Christenson, 1975; Clausen, Fineman, Henry,

c Whol, 1960; Davis, Sprague, Eerry, 1969; Lipman, DiMascio, Riatig, Kirson, 1978; Mcconnell, Cromwell, Bialer, Son, 1964; Morris, Macgillivray, \& Mathieson, 1955 ; Andree, Law, \&obbins; spencer, 1970).

However, Gadow (1985) reported that educably mentally retarded children responded favorably to stimulant medication. He attributed the previous negative findings to poor subject selection and inadequate dependent measures. Payton, Burkhart, Hersen, and Helsel (1989) studied the effect of dextroamphetamine and methylphenidate on 3 AD-HD mentally retarded children using a single case design targeting movement and on-task behavior. Two of the 3 subjects demonstrated marked changes in behavior and the third showed some improvement. Additional study will likely provide greater insight into the effectiveness of stimulant medication with hyperactive chilaren of subnormal intelligence (Brown, Ebert, \& Minichiel10, 1985).

Behavioral treatments for $A D-H D$ in mentally retarded children have been less thoroughly studied. Two case studies have been reported in the literature. The first used differential reinforcement of other behavior with feedback to treat attention problems, distractibility, and passivity in a mentally retarded 14-year-old female (Alvarez \& Londono, 1982). Fejes and Prieto (1987) 
investigated whether relaxation could be learned by a hyperactive, moderately mentally retarded boy. Results indicated that the child was able to learn the techniques as indicated by EMG. However, the extent to which treatment improved the child's overall symptoms was less we11-documented.

Fisher, Burd, Kuna, and Berg (1985) suggested that $A D D$ and $A D-H D$ may actually exist at higher rates among children with other disabilities. These authors suggested that AD-HD symptoms may be the most manageable component of the child's disabling condition. Moreover, they felt that even children who are motorically impaired could display AD-HD, although the symptom picture might be quite different. For instance, the child with cerebral palsy might fidget excessively and display inattention to tasks.

A final point made by these authors was that, in the absence of behavioral measures of inattention and impulsivity, physicians may prescribe medication for the symptom of overactivity, which is directly observable in the office. However, these are of lesser importance than the latter symptoms with regard to learning (Fisher, et. al., 1985). The work of these authors stresses the importance of using standardized measures to assess AD-HD. Next, rating scales and observational methods commonly used to assess AD-HD will be described. 
Asgegsment of AD-HD

AD-HD rating acales. The conners sceles were originally developed for use in drug research with AD-HD children (Conners, 1989). There are two versions of the scale for teachers, the conners' Teacher Rating scale-39 (CTRS-39) (Connerg, 1969) and the connerg' Teacher Rating Scale-28 (CTRS-28) (Goyette, Conners, Ulrich, 1978); two forms for parents, the conners' Parent Rating scale-93 (CPRS-93) (Conners, 1970) and the connerg' Parent Rating Scale-48 (CPRS-48) (Goyette, et. al., 1978); and the Abbreviated Symptom Questionnaires (ASO-P and ASQ-T) (Sprague sleator, 1973) for parents and teachers.

Each of the Conners's scales has been factor analyzed, and studies have been performed examining predictive validity (G1llberg Gillberg, 1983), discriminate validity (Homatidis Konstantareas, 1981; King Young, 1982; Kuehne, Kehle, McMahon, 1987), concurrent validity (Edelbrock, Greenbaum, conover, 1985; Sandoval, 1981), and construct validity (campbel1 \& steinert, 1978).

Researchers have demonstrated good test-retest reliability for the CTRS-39 and moderate test-retest reliability for the CPRs-93. Interrater reliability has been reported for teachers and classroom aides (Epstein a Nieminen, 1983), teachers and independent observers (Homatidis Konstantareas, 1981; Kazdin, Esveldt-Dawson, 
t Loar, 1983), mothers and fathers (Conners, 1973; Goyette, et. al., 1978), and parents and teachers (Glow, 1979; Goyette, et. al., 1978; Schaughency \& Lahey, 1985). In general, interrater reliability is best between teachers and worst between parents and teachers. However, Schaughency and Lahey (1985) found that mothers' ratings correlated significantly with teachers' ratings whereas fathers' ratings did not. The factors of the CTRS-39 are presented in Appendices A through G.

The Conners" Teacher Rating Scale has discriminated normal from hyperactive children, differentiated medicated and nonmedicated hyperactive children, and has been shown to correlate with classroom behavior (Loney Milich, 1982). However, when Loney and Milich (1982) attempted to separate children on the basis of hyperactivity and aggression, they found that none of the factors correlated with only one of these dimensions. For instance, the Conners Hyperactivity Factor was found to correlate .44 with measures of aggression from chart ratings. Therefore, Loney and Milich (1982) began work on subscales that would provide "purer" measures of hyperactivity and aggression/oppositional behavior.

The IOWA conners Teacher Rating scale (Loney a Milich, 1982) consists of two five-item subscales from the CTRS-39 (Conners, 1969) designed to assess Inattention/Overactivity (IO) and Aggression (A). Loney 
and Milich (1982) noted that the traditional Conners' Hyperactivity Factor and Hyperactivity Index contain items with aggressive/oppositional content. They stated that samples selected on the basis of the conners Hyperactivity Index will include children who are both hyperactive and aggressive.

Items from the CTRS-39 (Conners, 1969) that were significantly correlated with empirically derived Hyperactivity or Aggression factors were used in developing the IowA conners scales. Items that correlated significantly with the hyperactivity ratings from chart data but not with aggression ratings were retained for the Io scale. Items that were significantly correlated with aggression ratings but not hyperactivity ratings were used in constructing the $A$ scale.

Pelham, Milich, Murphy, and Murphy (1989) used the scale with 608 boys and girls and presented means, standard deviations, and cut-off scores for the IOWA-IO and IOWA-A Scales. A cut-off score of 11 was suggested for the Io scale and a cut-off score of 9 was suggested for the A scale.

These versions of the conners' Teacher Rating scale are important since they distinguish between children with problems associated with AD-HD, those with aggression/oppositional problems, and those with both sets 
of symptoms. The IOWA Conners Scales are located in Appendices $H$ and $I$.

Observational coding systems. A final method for assessing hyperactivity is direct observation for the purposes of diagnosis and treatment planning. It is popular to supplement Interview and checklist data with observation (Morris collier, 1987). With this in mind, several observation systems have been evaluated (Abikof a Gittleman, 1985; Abikoff, Gittleman, \&lein, 1977; 1980; Atkins, Pelham, Licht, 1985; Blunden, spring, a Greenberg, 1974; Mayes, 1987; Milich, Loney, Roberts, 1986; Roberta, 1986; Vincent, Williams, Harris, G Duval, 1981). These observational systems were designed for both playroom (Mayes, 1987 ; Milich, et. al., 1986; Roberts, 1986) and classroom environments (Atkins, et. al., 1985; Blunden, et. al., 1974; vincent, et. 1., 1981) and allow the coding of several important behaviors. The classroom codes help to objectify observation in the school, and the playroom codes are such that they may be recreated in a clinic setting. In addition to providing information for diagnosis and treatment planning, these observation systems are valuable research tools, pointing to symptoms most predictive of the disorder (Abikoff, et. al., 1977; 1980) and those which tend to persist over time (Milich, et. al., 1986). 
The Abikoff system (Abikoff, et. al., 1977; 1980; Abikoff \&ittelman, 1985) is a classroom observation code based on work by the stony Brook Group (Tonick, Friehling, \& warhit, 1973). With this code, 14 behavioral categories are sampled every 15 seconds. The code contains both timed (occurring throughout the interval) and untimed behaviors (occurring once during the interval). Average interobserver agreement was found to be relatively high (r $=.76)$ with children referred for hyperactivity.

Although the assessment methods described above have been extensively evaluated with normal IQ children, their utility with mentally retarded children has not been investigated. Very little empirical study has focused on assessing AD-HD in mentally retarded children. Epstein, et al. (1986) performed a study on children recelving special education. Their groups consisted of behaviorally disordered children, learning disabled children, mildly and moderately mentally retarded children, and nonhandicapped children. Using the Abbreviated Teacher Rating Scale (Sprague sleator, 1973) they found that between $14.3 t$ and $21.4 t$ of mentally retarded children scored above the generally recognized cut-of of 15 . Across all age groups, mentally retarded children received higher mean scores than the nonhandicapped children. The mentally retarded children received mean scores 3.8 and 2.7 points higher for older boys and girls. 
In younger boys and girls, the mentally retarded children received mean scores that were 6.2 and 5.5 points higher than the normal Io children. Differences were gignificant only for the younger categorles. When results were informally compared to data from other studies with normal children, rates were largely equivalent, except for younger handicapped girls who were twice as likely to be rated above cut-off scores (Arias o'Leary, 1984; Barling, O'Leary, Taffinder, 1983; o'Leary, Vivan, * Nisi, 1985; Ullmann, Sleator, \& Sprague, 1985; Werry * Hawthorne, 1976).

More research on assessment of AD-HD in mentally retarded children is needed. The goal of the present study was to extend results of other investigations by carefully focusing on the assessment of AD-HD in mentally retarded children. The psychometric properties of AD-HD assessment instruments have not been demonstrated with developmentally disabled children; reliability and validity indices have not been reported. Focuses of this study included interrater reliability and construct validity.

The study of AD-HD in mentally retarded children is important for several reasons. With additional information on the occurrence of AD-HD in mentally retarded children, diagnostic overshadowing may become less likely. For instance, if it is demonstrated that 
mentally retarded children sometimes show the constellation of behaviors found in normal Io children with AD-HD and that these behaviors can be reliably diagnosed in mentally retarded children, clinicians may be more likely to give both diagnoses when appropriate.

Second, there are numerous behavioral and pharmacological treatments for AD-HD. A better understanding of the components of AD-HD in mentally retarded children may be helpful in establishing the population subgroups for whom these treatments would be effective. Finally, studies have tested pharmacological treatment of $A D-H D$ in mentally retarded children (Alexandris Lundell, 1968; Aman, 1982; Anton \& Greer, 1969; Bell Zubeck, 1961; Christenson, 1975; Clausen, et. al., 1960; Davis, et. al., 1969; Gadow, 1985; Lipman, et. a1., 1978; Mcconnell, et. al., 1964; Morris, et. al., 1955; Payton, et. al., 1989; Spencer, 1970). Since many feel that pharmacological treatment of children should be carefully monitored (Gadow, 1988), assessment measures become extremely important. With psychometric properties of AD-HD instruments demonstrated among mentally retarded children, cut-off scores may be determined and the choice of treatment may be made easier.

specifically, this study added to existing literature in several ways. First, the children studied were rated on an observational measure in addition to checklist data. 
The only study on the assessment of AD-HD in mentally retarded children to date (Epstein, et. al., 1986) used only one measure of AD-HD, the conners Abbreviated symptom Questionnaire. In the present study, the expanded CTRS-39 and observations were used to examine AD-HD. Thereby, the adequacy of the CTRS and observations for discriminating differences between AD-HD and non-AD-HD groups among mentally retarded children was examined.

This study was the first to evaluate a standardized behavioral rating system, the Abikoff system (1977), with mentally retarded children. Thus, multi-method assessment of mentally retarded children with AD-HD was performed.

Another innovative aspect of this study is that the criteria for AD-HD listed in DSM-III-R (American Psychiatric Association, 1987) was used in assigning group membership. Interrater reliability on a checklist of DSMIII-R symptoms was obtained using teachers and teachers a ides.

In addition, Epstein, et. al. (1986) assessed AD-HD in normal children, mildly mentally retarded children, learning disabled children, and behaviorally disordered children. Here, the focus was on mild and moderate mental retardation and its relation to $A D-H D$. Four groups were included: mentally retarded children, AD-HD children, children with mental retardation and $A D-H D$, and normal control children. Including the group of mentally 
retarded non-AD-HD children, allowed the studying possibility that the CTRS simply measures a correlate of intelligence. Incorporation of the AD-HD group permitted the comparison of $A D-H D$ symptom severity between $A D-H D$ children with and without mental retardation. The IOWA Conners' Rating Scales were also used, allowing the identification of children who are Inattentive and Overactive, Aggressive, or both Inattentive/Overactive and Aggressive, within the larger groups of AD-HD alone and AD-HD plus mental retardation. The ldea that $A D-H D$ and conduct problems are separate but sometimes overlapping has not been evaluated previously with mentally retarded children, although with normal IQ children this has been a primary area for debate. Here, such fine-grained issues as well as the more general issue of differences between groups and the adequacy of AD-HD instruments for assessing mentally retarded children were addressed. 
METHOD

subiects and setting

One hundred boys ages 6 to 8 years from an area in the southern United states were studied. subjects were recruited through regular and special education classrooms. Participating teachers gent a parent consent form (Appendix $J$ ) home with each boy in the class. For those children returning the consent form, the teacher completed a DSM-III-R checklist that included the symptoms of $A D-H D$ and an intelligence screen was performed. Intelligence estimates were obtained using the Block Design and Vocabulary subtests of the Wechaler Intelligence Scale for Children (Wechsler, 1974). Scores were determined using the method described in sattler (1988). Children were matched on age and then assigned to groups based on scores from the DSM-III-R checklist and the IQ estimate.

Mentally retarded group $(n=25)$. These subjects received intelligence estimates at least two standard deviations below. The scores of the subjects were within the mild to moderate ranges of mental retardation. Children in this group were rated positively on fewer than 8 of the symptoms listed on the DSM-III-R (American Pychiatric Association, 1987) checklist.

Mentally retarded $A D-H D$ group $(n=25)$. These children obtained intelligence estimates at least two 
standard deviations below the mean within the mild to moderate ranges of mental retardation as described above. In addition, they received a score of at least 8 on the DSM-III-R (American Psychiatric Association, 1987) checklist.

AD-HD normal Io group $(n=25)$. Children in this group received intelligence scores above the cut-off for mental retardation. They were also rated positively on at least 8 of the symptoms on the DSM-III-R (American Psychiatric Association, 1987) checklist.

Normal control qroup $(n=25)$. A control group of normal IQ children without AD-HD was also studied. These children received intelligence scores within the normal range and were rated positively on fewer than 8 of the symptoms from the DSM-III-R (American Psychiatric Association, 1987) checklist.

Setting and Apparatus

Observations took place in the child's classroom during group teaching instruction during morning hours. Children were tested outside of the classroom for intelligence estimation.

Asgessment

Demographic information form (see Appendix J). Parents completed a demographic information form. Information included date of birth, age, sex, the child's class placement, and whether or not the child had ever 
been diagnosed $A D-H D$ or mentally retarded and by whom. The demographic form also questioned whether the child was taking any medication.

Inteldigence estimation. The Block Design and Vocabulary subtests of the Wechsler Intelligence scale for Children-Revised (WISC-R) (Wechsler, 1974) were used to estimate intelifigence. This short form of the WISC-R includes subtests that have good reliability $(.85$ and $.86)$, correlate moderately with the Full scale (.68 and .74 ), and have been described as good measures of $\mathrm{g}$ (Sattler, 1988).

DSM-III-R checklist (see Appendix L). Teachers completed a Likert rating form containing the symptoms for AD-HD listed in DSM-III-R (American Psychiatric Association, 1987).

conners' Teacher Rating Scale-39 (CTRS-39) (Conners, 1969). Teachers completed the CTRS-39, an assessment instrument for AD-HD. Appendices $E$ through $\mathrm{K}$ display the factors of the CTRS-39. Items comprising the IOWA Conners' Scale (Loney \& Milich, 1982) were extracted from the CTRS-39 to compute ratings on the Inattention/Overactivity (see Appendix $\mathrm{H}$ ) and Aggression (aee Appendix I) subscales.

Direct observation (see Appendix M). Ten children from each of the four groups were observed using the Abikoff system $(1977 ; 1985)$. 
Observers, two undergraduate students, were present in each classroom on one occasion prior to the collection of formal data. During these sessions, the observers practiced using the coding system, and the children adapted to the observers' presence.

Each observation perlod was 25 minutes long. During this period, up to 5 children were observed. The observers were seated away from the children in a corner of the classroom and wore headphones attached to a tape recorder that announced the beginning of each interval. Observers were equipped with data sheets, clipboard, and pencil and were instructed to remain as unobtrusive as possible (ignoring interaction attempts, looking away briefly when children looked at them). Each child was observed for 4 consecutive 15 second intervals 5 times. After one child was observed for 4 intervals, another child was observed. The order of children observed was randomly determined. Observations continued until each child was observed 5 times, yielding a total of five minutes of observational data per child within a session. The children were observed on 4 separate occasions resulting in 20 minutes of observational data per child. A total score was computed for each child by summing scores across behavioral categories from the coding system. 
During observations, the following target behaviors were recorded:

1.) Interference. This category referred to verbal or physical behavior or nolses that are potentially disturbing to others. It included interrupting the teacher or another student (calling out, starting a conversation), producing sounds without permission (vocalizations, screams, whistles), annoying behavior (nonverbal interruption, tapping, sitting in another's desk, moving another's or own chair), and clowning (mimicking, kicking an object, playing games during work, showing of $w$ ithout a request). In order to score this category, the behavior did not have to occur throughout the entire interval.

2.) off-task. This category was scored when the child attended to stimuli other than the teacher or the assigned work. This category included attending to objects, people, or parts of the body to the total exclusion of the task for an entire interval.

3.) Noncompliance. This behavior reflects a failure on the part of the child to follow teacher instructions. After the teacher gave a command, the child had one full interval to begin complying. If the child did not comply, this category was scored until the child performed the requested activity. 
4.) Minor motor moyement. Behaviors that are indicative of fidgeting and restlessness were included in this category. These included in-seat movements such that there was an observable movement of the lower buttocks, that part of the buttocks that is in contact with the seat of the chair. For example, if the child slid in his or her seat, twisted, turned, wiggled, or lifted buttocks from the seat, this category was scored. Also included were rocking, repetitive movements (at least two back and forth movements) where the child moved from the waist up in a back and forth manner. Movements of the chair were also coded when the child lifted two chair legs off the floor.

5.) Gross motor behavior. This category referred to motor activity that results in the child's leaving his or her seat and standing on one or both legs and vigorous motor activity while not seated. Examples included jumping out of seat, running, crawling, twirling, acrobatics, and swinging between two seats or desks.

6.) Qut-of chair behavior. Here, the child remained out of chair for one full interval after the interval in which he or she first left the seat.

7.) Physical agaression. The child made a forceful movement directed at another person, either directly or by utilizing a material object, such as an extension of the hand. Included were blocking someone's way, tripping, 
kicking, hitting, throwing objects, pinching, and biting. The child destroyed other's materials or possessions or school property. Examples included tearing or crumpling another's work, breaking crayons, pencils, etc., writing on another child's work, the desk or school property. If the child grabbed material in a sudden manner whether the material was the child's or someone else's this category was also scored.

8). Threat or verbal aggression. The child used abusive language or gestures to other children or the teacher. Examples included cursing, threatening, teasing, criticizing, and physical gestures.

9.) Solicitation of teacher. This category included behaviors directed at gaining the teacher's attention. It included leaving the seat and going up to the teacher, raising one's hand, and calling out to the teacher.

10.) Absence of behavior. This category was scored when none of the inappropriate behaviors defined above occurred during the interval. 


\section{RESULTS}

Reliability of Observations

Four undergraduate students served as raters after being trained to 90 agreement or above on the coding system. Two of the raters collected reliability data on half of the observations. Kappa's were computed on each observation session. Kappa's ranged from .38 to 1.0 with a mean Kappa value of .74 . Demographic characteristics

Demographic characteristics for the subject groups are presented in Table 1 . There were no differences between the groups regarding age. A one-way Analysis of Variance (ANOVA) on IQ score showed significant differences between the groups $[F(3,96)=99.7, p<.001]$. The groups differed in highly predictable ways. Both mentally retarded groups had a mean IQ significantly lower than the other two groups.

Reliability of Diagnosis

For 25 subjects, teacher's aids also completed the DSM-III-R checklist. The Pearson Product Moment Correlation was used to examine the association between teacher and teacher's aid ratings. A correlation coefficient of .86 was found. Within this subsample, 24 of 25 students were similarly classifled by their teacher and the teacher's aids. 
Table 1

Age, to, Race, and class Placement by Group

\begin{tabular}{lll}
\hline Normal & AD-HD & Mentally Mentally \\
& Retarded
\end{tabular}

Retarded/AHDD

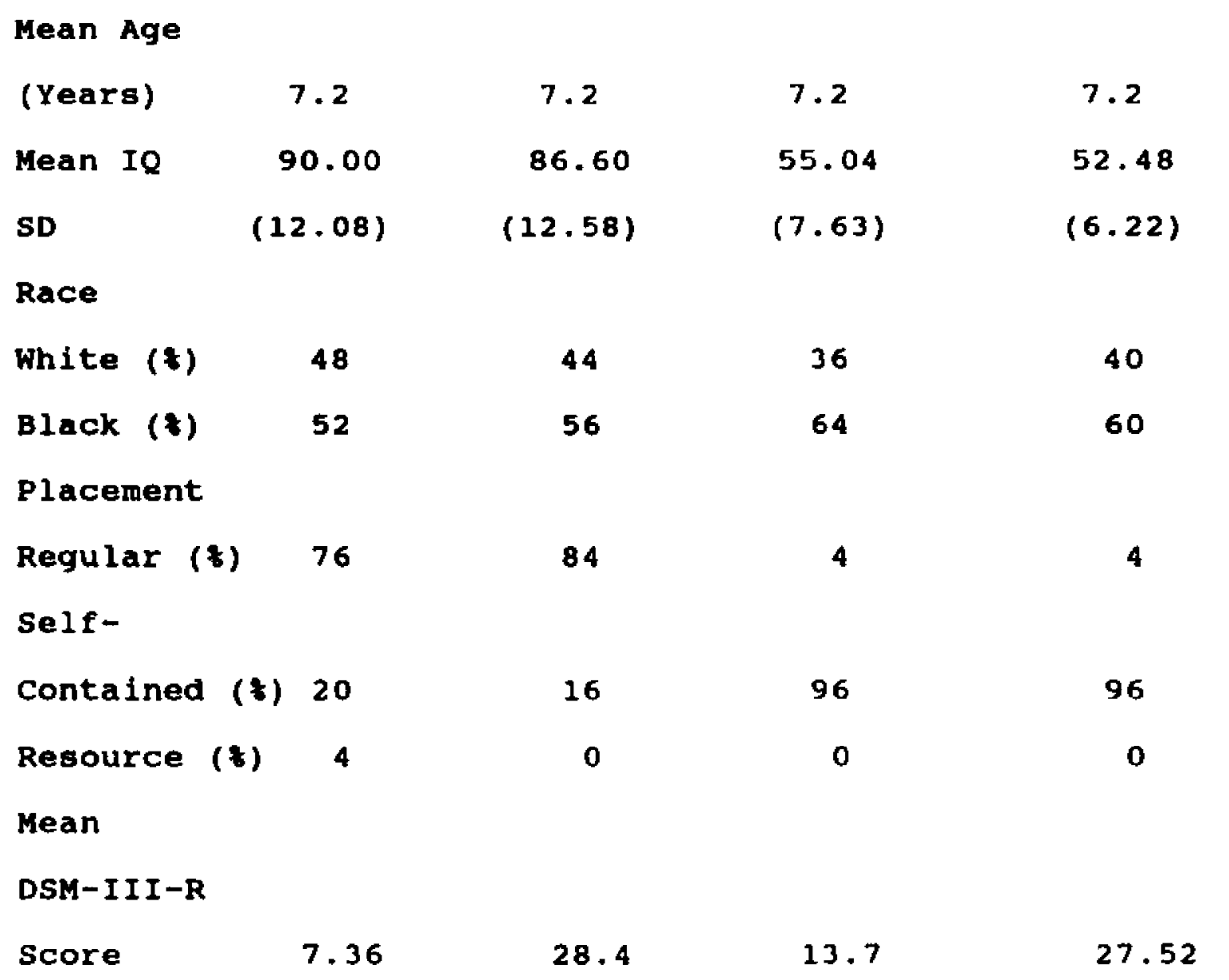




\section{Differences Between Groups}

Nine one-way ANOVA's were performed on the CTRS Factors and IOWA-Conners Scales. Given the large number of comparisons, the Bonferroni correction was used to decrease the probability of making Type I errors.

significant differences were found between the groups on each of the nine measures. On four of the measures, Hyperactivity Factor $[F(3,96)=27.28, \mathrm{p}<.001]$, Conduct Problem Factor $[F(3,96)=19.57, \underline{p}<.001]$, Hyperactivity Index $[F(3,96)=31.45, R<.001]$, and IOWA InattentionOveractivity scale $[F(3,96)=19.60, p<.001]$, both the AD-HD group and the mentally retarded AD-HD group received significantly higher ratings than the normal and mentally retarded groups. Figure 1 shows the means plotted for each group on the Hyperactivity Factor, Conduct Problem Factor, Hyperactivity Index, and IOWA-IO Scale.

on the Emotional overindulgent Factor, both AD-HD groups were rated significantly higher than the normal and mentally retarded groups $[F(3,96)=16.07, Q<.001]$. In addition, however, mentally retarded subjects were rated higher than the normal control group. On the AnxiousPassive Factor, both mentally retarded groups received ratings significantly above the normal group $[F(3,96)=$ 4.44, $2<.07]$. Figure 2 shows the mean score on the Emotional/Overindulgent and Anxious/Passive Factors plotted for each group. 

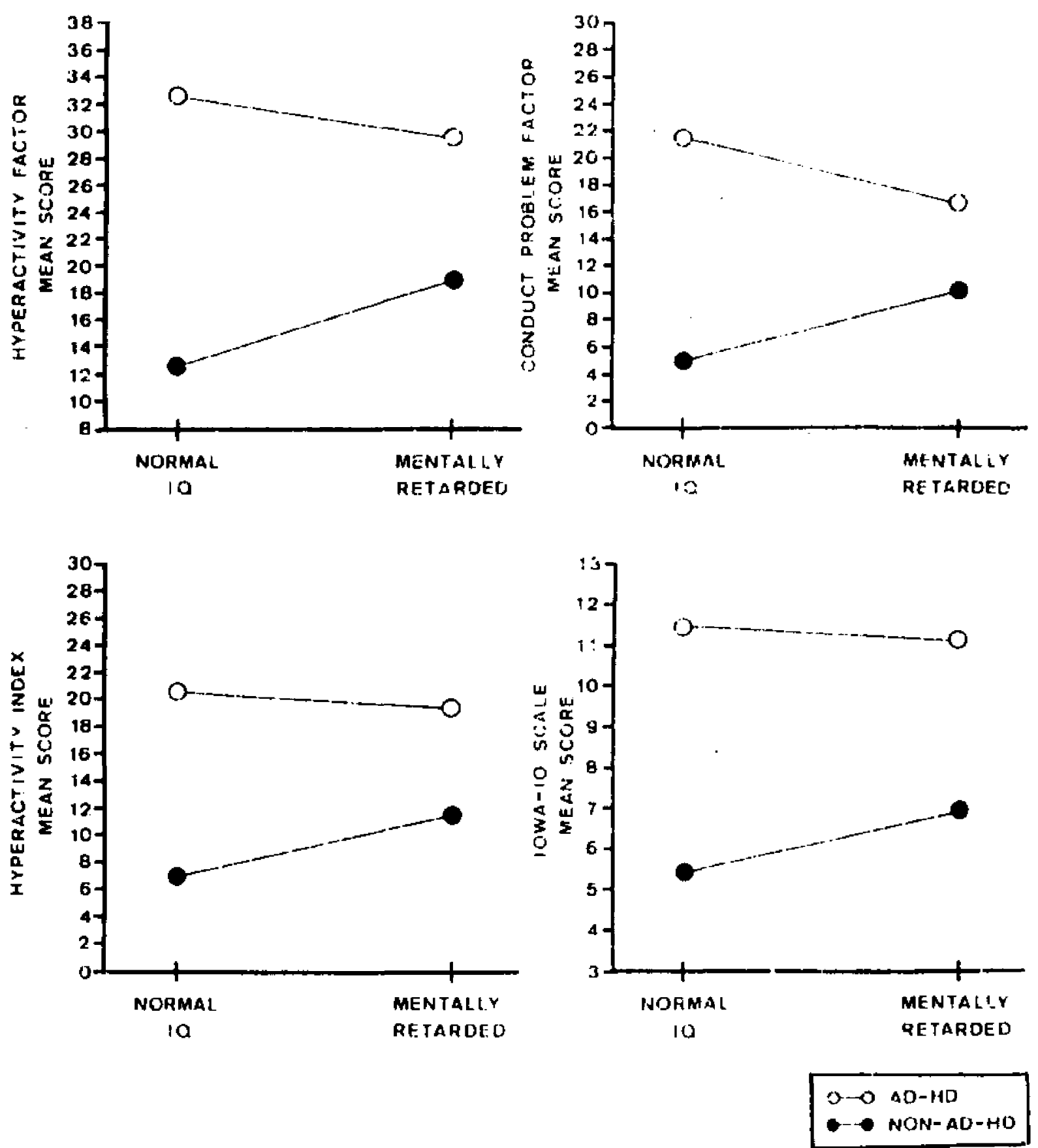

Figure 1. Mean Scores on the conners' Hyperactivity Factor, Conduct Problem Factor, Hyperactivity Index, and IOWA-IO scale sor the mentaliy retarded, mentally retarded $A D-H D, A D-H D$; and inormal groups. 

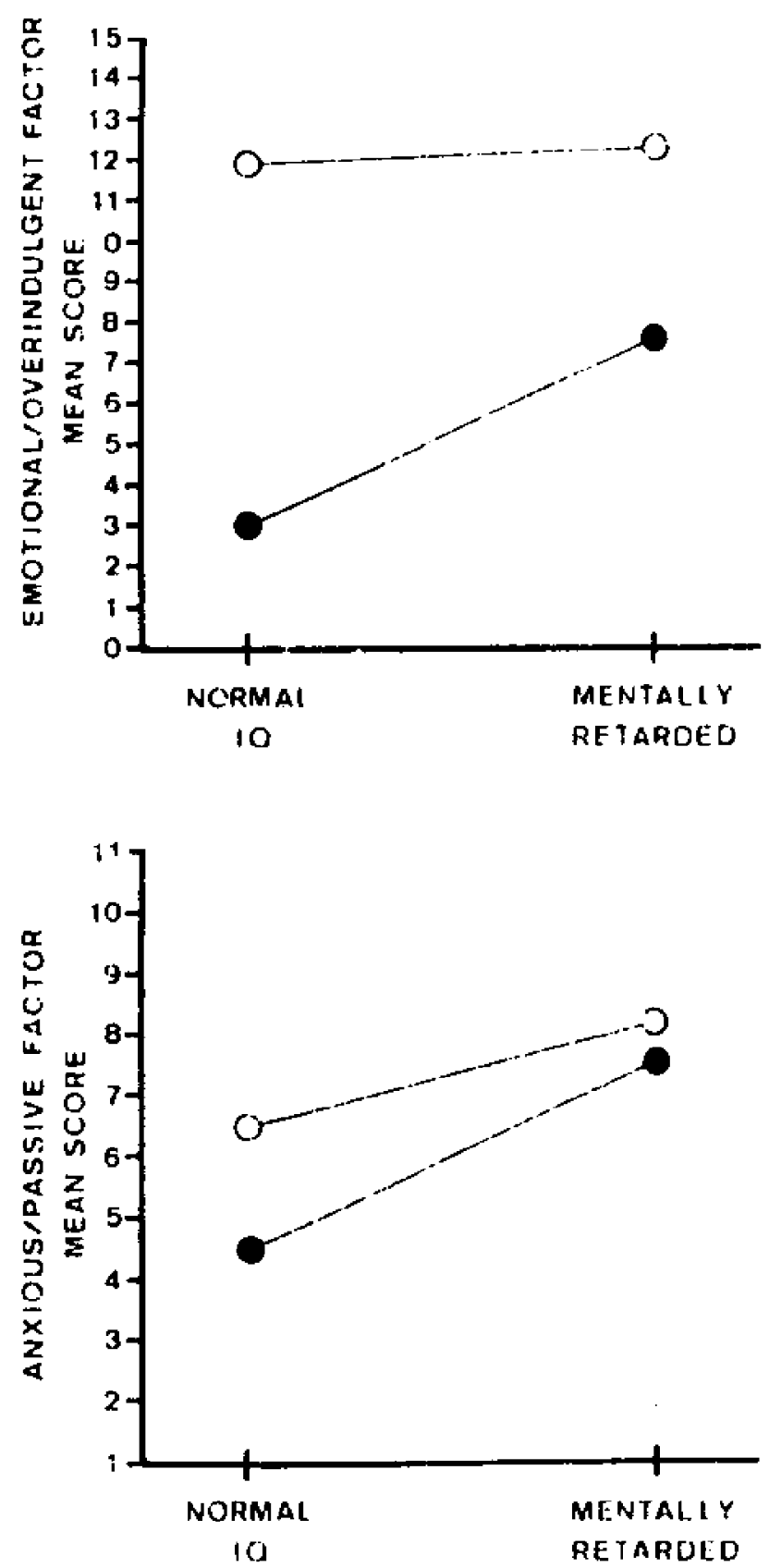

O-O AD-HC

$\longrightarrow$ NON-AD-HD

Figure 2. Mean Scores on the Conners' Emotional/ overindulgent and Anxious/Passive Factors for the mentally retarded, mentally retarded $A D-H D, A D-H D$, and normal groups. 
Both AD-HD groups were rated oignificantly higher than the normal group on the Daydream-Attention Factor $[F(3,96)=5.97, g<.001]$. Similar results were found for the IOWA-A Scale $[F(3,96)=15.42,2<.001]$. In addition, the AD-HD group was rated significantly higher than the mentally retarded group on the IOWA-A Scale. significant differences were also found on the Asocial Factor $[\mathrm{F}(3,96)=6.36, \mathrm{p}<.001]$. Specifically, the AD-HD group was rated higher than the normal and mentally retarded AD-HD groups. Means and standard deviations for each group on the Conners' factors and IOWA scales are presented in Table 2. Figure 3 shows the mean score on the Daydream/Attention Problem Factor, IOWA-A Scale, and Asocial Factor plotted for each group. observations

A one-way ANOVA was performed on observation total scores. The $A D-H D$ and mentally retarded $A D-H D$ groups received ratings significantly higher than the mentally retarded and normal groups $[F(3,36)=5.37,2<.07]$. Means and standard deviations are displayed in Table 3 . Figure 4 shows the means plotted for each group. Differential Validity

Tables 4 and 5 show the intercorrelation matrices for the Conners' Factors and IowA scales among the mentally retarded and normal IQ groups. Several differences are apparent. Although the Conners' Conduct and 
Table 2

Hean and standard Dyiatione for the conners factore and rown scales by Group

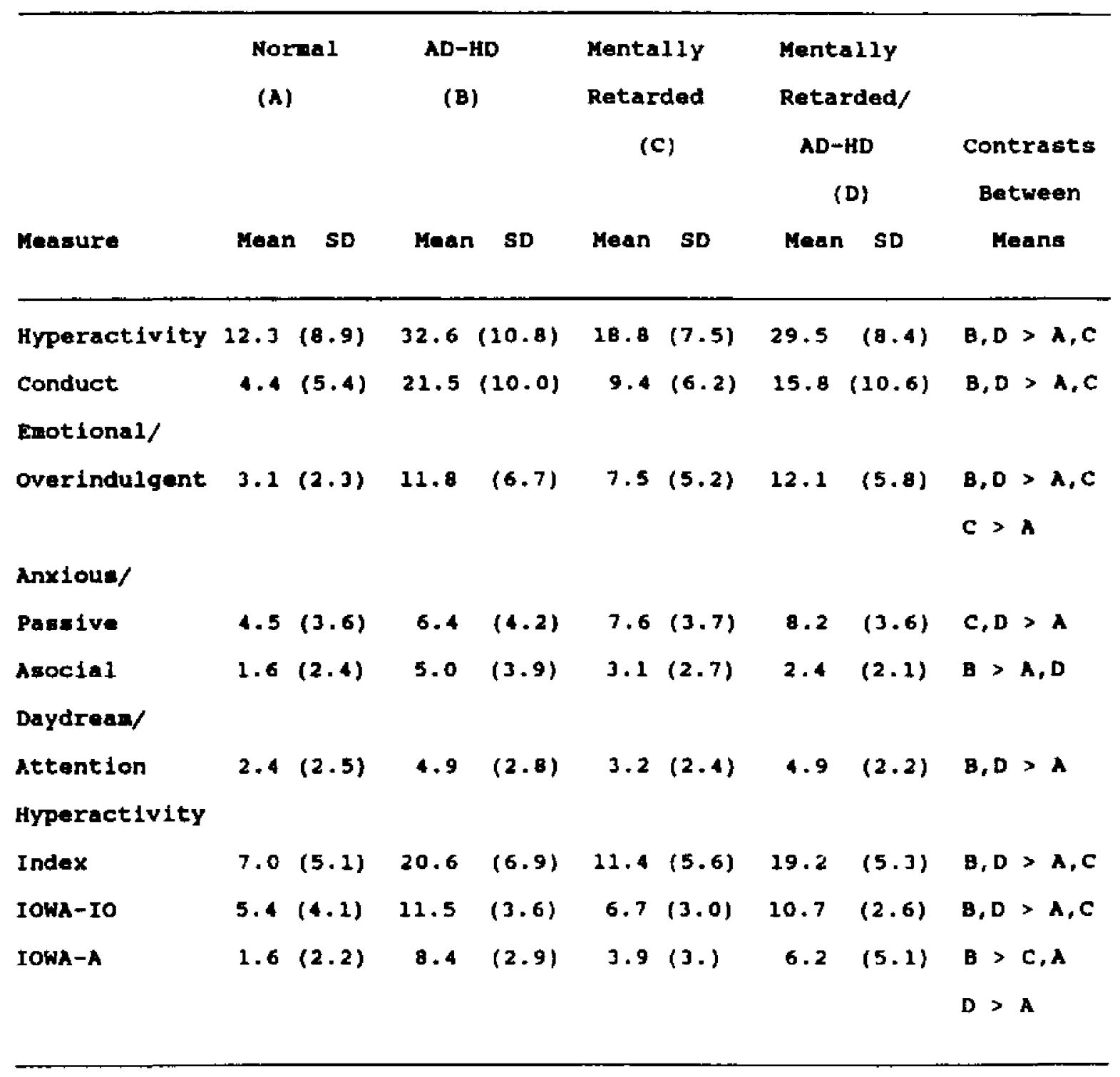

Note: Contrasts are reported for means significantly different at $2<.07$. 

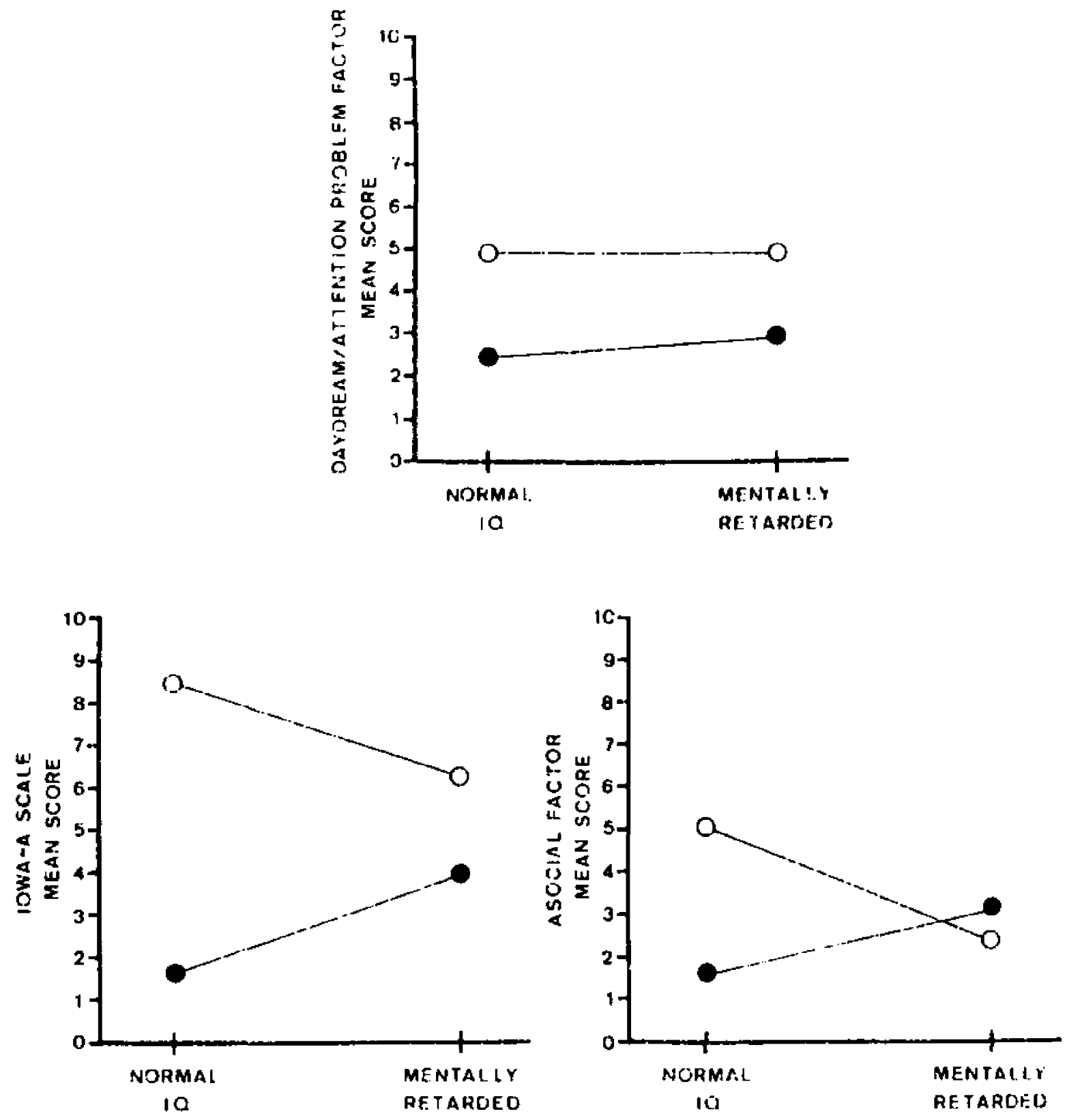

Fiqure 3. Mean scores on the Conners' Daydream/Attention Problem Factor. IOWA-A scale and Asocial Factor for the mentally retarded, mentally retarded $\mathrm{AD}-\mathrm{HD}, \mathrm{AD}-\mathrm{HD}$, and normal groups. 
Table 3

Hant and standard Deviations for obaryation Total score by Group

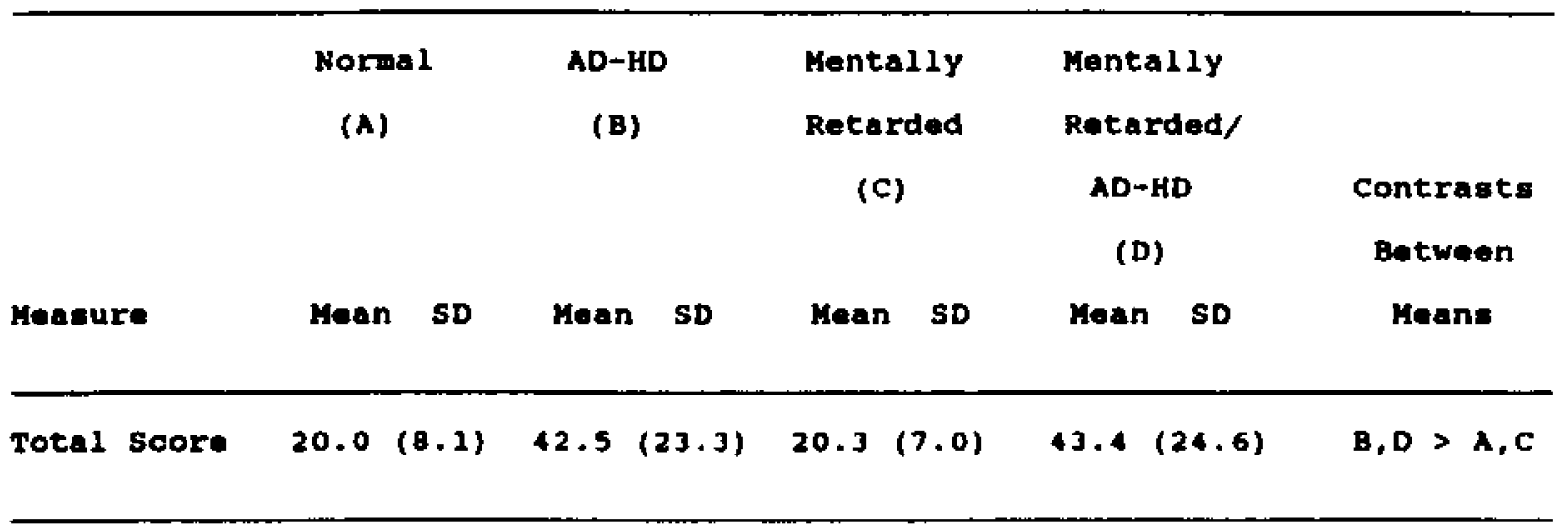

Note: Contrasts are reported for aons agniflcantly different at $D<.07$. 


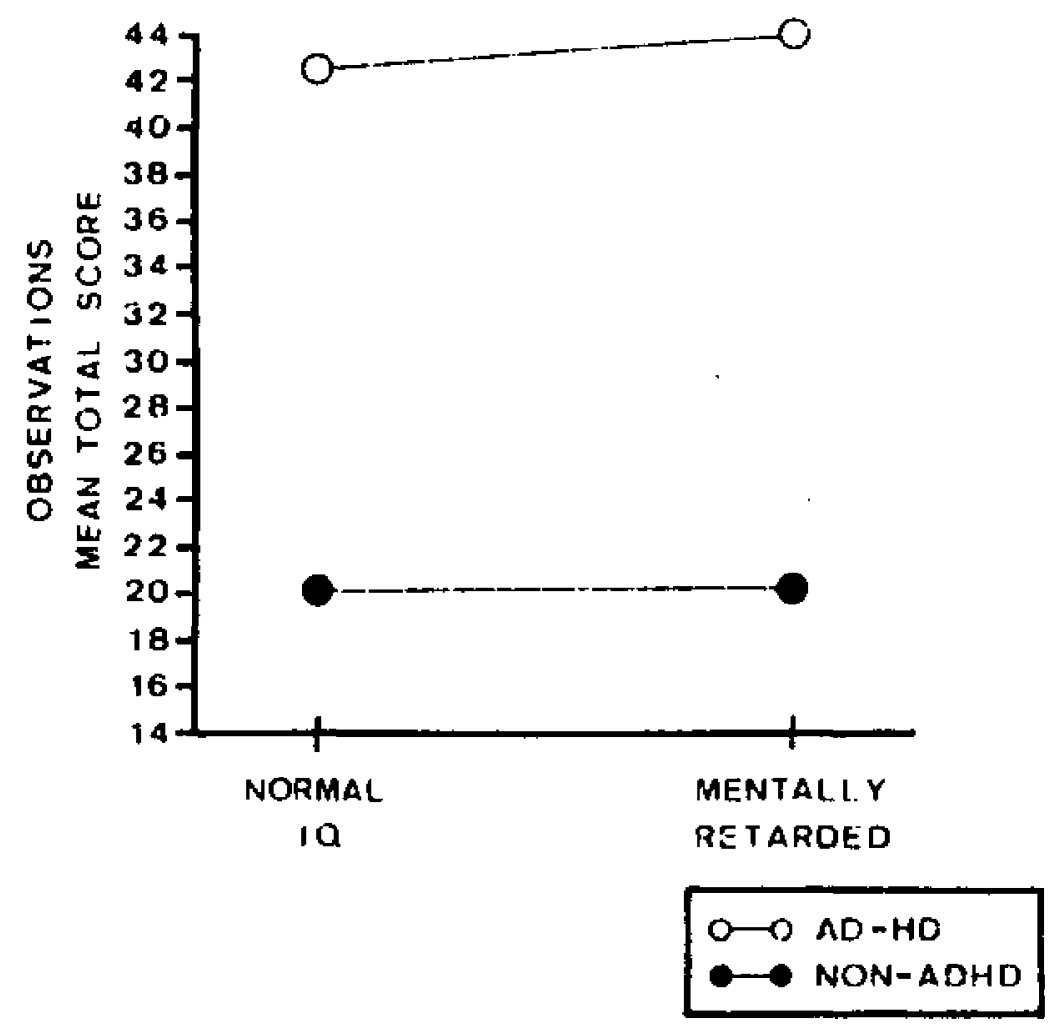

Figure 4. Mean observation total scores for the mentaliy retarded, mentaliy retarded $A D-H D, A D-H D$. and normal groups. 
Table 4

Intercorcelations of Teacher Ratinge on the conners Factore and rowh scales within the Montaly Retarded Grouns

\begin{tabular}{|c|c|c|c|c|c|c|c|c|c|}
\hline \multirow[b]{2}{*}{ Measure } & \multicolumn{7}{|c|}{ Conners Factors } & \multirow{2}{*}{ IOWA } & \multirow{2}{*}{ Scales } \\
\hline & 1 & 2 & $\mathbf{3}$ & 4 & 5 & 6 & 7 & & \\
\hline
\end{tabular}

\begin{tabular}{|c|c|c|c|c|c|c|c|c|}
\hline 2 & $.81 *$ & & & & & & & \\
\hline 3 & $.64 *$ & $.71 *$ & & & & & & \\
\hline 4 & -.17 & $-.42 * t$ & .01 & & & & & \\
\hline 5 & .15 & $.31 *$ & .31 & -.07 & & & & \\
\hline 6 & .13 & .01 & .02 & .16 & .21 & & & \\
\hline 7 & $.95 *$ & $.75 *$ & $.74 t$ & -.09 & .15 & .08 & & \\
\hline Io & $.88 * 6$ & $.56 * *$ & $.41 * *$ & -.05 & .07 & .26 & $.85 * *$ & \\
\hline $\boldsymbol{\lambda}$ & $.74 *$ & $.95 * *$ & $.67 * t$ & $-.44 * *$ & .27 & $=.03$ & $.67 * t$ & $.46 t *$ \\
\hline
\end{tabular}

Hota: 1 - Hyparactivity Pactor; 2 = Conduct Factor; 3 = Emotional/ Overindulqent Factor; 4 - Anxious/Paseive Factor; 5 = Anocial Factor: 6 = Daydream/attention Problea Factor; 7 = Hyperactivity Indax; Io - IOWA-Inattention Overactivity Scale; $\mathrm{A}$ = IOWA-Aggressive oppositional scale.

$\| \mathbf{P}<.05 \# \mathbf{2}<.01$ 
Table 5

Intercorrelations of Teacher Retings of the Connors Factore and row

seader within the Normal Io groupr

\begin{tabular}{|c|c|c|c|c|c|c|c|c|c|}
\hline \multirow[b]{2}{*}{ Meature } & \multicolumn{7}{|c|}{ Conners Factors } & \multicolumn{2}{|c|}{ IONh scales } \\
\hline & 1 & 2 & 3 & 4 & 5 & 6 & 7 & Io & $\mathbf{A}$ \\
\hline 1 & & & & & & & & & \\
\hline 2 & $.89 \star *$ & & & & & & & & \\
\hline 3 & $.78 *$ & $.87 * *$ & & & & & & & \\
\hline 4 & .01 & -.15 & .11 & & & & & & \\
\hline 5 & .73 & $.73 *$ & $.6 B$ & -.02 & & & & & \\
\hline 6 & .68 & .44 & .37 & .15 & .26 & & & & \\
\hline 7 & $.97 * *$ & $.91 *$ & $.05 * 4$ & -.01 & $.74 *$ & $.62 * t$ & & & \\
\hline Io & $.91 * *$ & $.68 * t$ & $.57 *$ & -.06 & $.61 * \star$ & $.73 * \star$ & $.86 * *$ & & \\
\hline $\mathbf{A}$ & $.86 * *$ & $.97 * *$ & $.82 * *$ & -.13 & $.67 * *$ & .43 & $.86 * *$ & $.65 * t$ & \\
\hline
\end{tabular}

Note: 1 = Hyperactivity Factor; 2 - Conduct Factor; 3 = Emotional/

Overindulgent Factor; 4 = Anxious/Pasafve Factor; 5 - Anocial Factor;

6 - Daydreavattention Problen Factor; 2 - Hyperactivity Index;

Io - Iowh-Inattention overactivity scale; A Iowh-Aggteseive Oppositional scale.

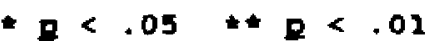


Hyperactivity Factors were significantly correlated in both groups, the association was stronger within the normal IQ group $(\mathrm{r}=.89, \mathrm{p}<01)$ as compared to the association within the mentally retarded group $(r=.81, p$ $<.01)$. The contrast is more striking when the intercorrelations between the IOWA-IO and IOWA-A scales are compared. Within the normal IQ group, the correlation coefficient was .64 ( $\mathrm{p}<.01$ ), whereas in the mentally retarded group the coefficient was .46 ( $2<.01)$.

Another difference is that the Daydream/Attention Problem factor was significantly correlated with the Hyperactivity Factor $(r=.97, \mathbf{p}<.01)$, Conduct Factor ( $r$ $=.91, \mathbf{p}<.01)$, Emotional/Overindulgent Factor $(r=.85$, $\mathrm{p}<.01)$, Asocial Factor $(r=.74, \mathrm{p}<.01)$, Hyperactivity Index $(r=.62, p<.01)$, IOWA-IO Scale $(r=.87, p<$ $.01)$, and IOWA-A Scale $(r=.85, \mathrm{p}<.01)$ among the normal IQ subjects. Within the mentally retarded group, the Daydream/Attention Problem Factor was not significantly correlated with any other measure.

within the mentally retarded group, the Anxious/Passive Factor was negatively correlated with the Conduct Factor $(r=-.42, \mathrm{p}<.01)$ and IOWA-A Factor $(\mathbf{r}=$ $-.44, \mathrm{p}<.01$ ). Within the normal group, the Anxious/Passive Factor was not significantly correlated with any other measure. 
In addition, the Asocial Factor was significantly correlated with the Hyperactivity factor $(r=.72$, $p<$ $.01)$, Conduct Factor $(r=.73, p<.01)$, Daydream/Attention Problem Factor $(r=.74, p<.01)$, Emotional/Overindulgent Factor $(r=.6 B, 2<.01)$, IOWA-IO Scale $(r=.61, p<.01)$, and IOWA-A Scale $(r=.66, p<$ $.01)$. Among the mentally retarded subjects, the Asocial Factor was significantly correlated with the conduct Factor $(r=.31, \mathrm{p}<.05)$ and the Emotional/overindulgent Factor $(r=.31, p<.05)$ but was not significantly correlated with any of the other Factors or IOWA scales.

For both the normal and mentally retarded groups, the Conners' Hyperactivity Index was significantly correlated with the Hyperactivity Factor (mentally retarded: $r=.68$, $\mathrm{p}<.01 ;$ normal: $\mathbf{r}=.94, \mathbf{p}<.01)$, conduct factor (mentaliy retarded: $\mathrm{r}=.44, \mathrm{p}<.05$; normal: $\mathrm{r}=.75$, $\mathrm{p}<$ .01 ), and IOWA-IO Scale (mentally retarded: $r=.84, p<$ .01 ; normal: $r=.73, p<.01$ ). Within the normal group, the Daydream/Attention Problem Factor was also significantly correlated with the Hyperactivity Index ( $=$ $.62, \mathrm{p}<01$ ). A significant association was not found with the Daydream/Attention Problem Factor and the Hyperactivity Index within the mentally retarded group. However, the Emotional/Overindulgent $(r=.74, \mathfrak{Q}<.01)$ and IOWA-A Scale $(r=.66, \mathrm{p}<.01)$ correlated 
significantly with the Hyperactivity Index in the mentally retarded group.

Table 6 shows the percentage of subjects in each group with scores above the cutoff on the conners Hyperactivity Index, IOWA-IO scale, and IOWA-A scale. In addition, Table 6 shows the percentage of subjects in each group who were above the cutoff on both the IOWA-IO and IOWA-A scales. Visual inspection of the data shows that the IOWA-IO scale identified fewer subjects as behaviorally disturbed relative to the Hyperactivity Index in both of the AD-HD groups. Within the normal IQ group, the IOWA-IO scale identified 18 of the 22 subjects that had been Identified with the Hyperactivity Index, whereas within the mentally retarded group only 14 of the 22 subjects identified with Hyperactivity Index.

Eight subjects from the mentally retarded non-AD-HD group were above the cut-off on the Hyperactivity Index. Only 2 subjects from this group were above the cut-off when the IOWA-IO Scale was used.

Ten children in the AD-HD group and 6 children from the mentally retarded AD-HD group scored above the cut-off on both the IOWA-IO and IOWA-A Scales. It should be noted that fewer mentally retarded subjects than normal subjects were identified across each of the IOWA scales. 
Table 6

Percentage of students Above the cut-off on the Hyperactivity

Index. IOWA-10 scale, IOWA-A Scale, and both IOWA Scales

\begin{tabular}{lcccc}
\hline \multicolumn{1}{c}{ Measure } & Normal & AD-HD & $\begin{array}{c}\text { Mentally } \\
\text { Retarded }\end{array}$ & $\begin{array}{c}\text { Mentally } \\
\text { Retarded/AD-HD }\end{array}$ \\
\hline $\begin{array}{l}\text { Hyperactivity } \\
\text { Index }\end{array}$ & 1 & 22 & 8 & 22 \\
(Percent) & $(4)$ & $(88)$ & $(32)$ & $(88)$ \\
IOWA-IO & 3 & 18 & 2 & 14 \\
(Percent) & $(12)$ & $(72)$ & $(8)$ & $(56)$ \\
IOWA-A & 0 & 12 & 3 & 9 \\
(Percent) & $(0)$ & $(48)$ & $(12)$ & $(36)$ \\
IOWA-IO and & & & & 6 \\
IOWA-A & 0 & 10 & 1 & $(24)$ \\
(Percent) & $(0)$ & $(40)$ & $(4)$ & \\
\hline
\end{tabular}




\section{DISCUSSION}

AD-HD children and mentally retarded AD-HD children differed from normal and mentally retarded children on five of the measures used in this study. Using observational data, similar differences were found. In only one instance, on the Asocial Factor, did the AD-HD and mentally retarded AD-HD groups differ significantly. From these results, it appears that a subset of mentally retarded children show a pattern of behavior resembling $A D-H D$ as it occurs among children of normal intelligence. Criteria for diagnosing AD-HD in normal IQ children also apply to mentally retarded children. This conclusion was reached since there were no significant differences between the $A D-H D$ and mentally retarded $A D-H D$ groups regarding symptoms used for diagnosis. It seems important that mentally retarded children be included in research used for revising diagnostic systems, since AD-HD appears to occur in mentally retarded individuals.

The DSM-III-R checklist used in this study was shown to be a reliable measure of AD-HD symptoms, Although a Likert type checklist has been used previously for identifying children with AD-HD, reliability data was not reported (Newcorn, et. al, 1989). Here, a moderate to high interrater reliability coefficient was obtained between teachers and teacher's aids. 
clear IQ differences were found between the AD-HD and mentally retarded AD-HD groups. In addition, a sample of mentally retarded children without AD-HD symptoms was identified. Although results presented here do not preclude a contribution of CNS damage to the development of $A D-H D$, there is additional suggestion that attributing AD-HD to brain damage is an oversimplified hypothesis.

Previous investigators have examined the relation between inattention, overactivity, and aggressive/ oppositional symptoms (Hinshaw, 1987). Here, these components were studied within both mentally retarded and normal IQ samples. As found in previous research, conduct- and hyperactive-type symptoms were significantly correlated. This association was found among both the normal IQ and mentally retarded subjects. However, the relation appeared to be stronger within the normal IQ groups.

Although mentally retarded AD-HD children were rated significantly higher than the mentally retarded group on the conduct Factor of the CTRS, there was not a significant difference between these groups on the IOWA-A scale which is considered a more "pure" measure of oppositional and aggressive behavior (Loney \& Milich, 1982). These results could be due to items describing emotional and anxiety symptoms on the CTRs conduct Factor which share variance with other conners Factors. 
Therefore, the conclusion is that mentally retarded AD-HD children are probably not more aggressive/oppositional than children who are simply mentally retarded. This distinction is important since conduct-type symptoms have been associated with poorer prognosis in adulthood for normal IQ children with AD-HD (Hinshaw, 1987). Whether aggressive symptoms in mentally retarded students is associated with poorer outcome in adulthood is a question for future study.

Attention problems correlated significantly with symptoms of both hyperactivity and conduct disorder among the normal subjects. However, the opposite was found for the mentally retarded children. The conners Attention Problem Factor did not correlate with any other measure among the mentally retarded subjects. In addition, children from the mentally retarded AD-HD group were not rated significantly above their non-AD-HD mentally retarded peers on this factor. These findings may be due to an association between attention problems and mental retardation in general.

DSM-III-R provides 14 symptoms for diagnosing AD-HD. Three of these symptoms are related to attention problems. since the diagnosis requires the presence of at least 8 symptoms, using the current version of DSM-III-R (American Psychiatric Association, 1987) would be unlikely to overinclude mentally retarded children who display only 
attention problems. However, in the past, DSM-III had the categories Attention Deficit Disorder (ADD) and Attention Deficit Disorder with Hyperactivity (ADD-H) (American Psychiatric Association, 1980). As applied to mentally retarded children, using the categories in DSM-III might lead to overincluding mentally retarded children who display only attention problems. Thus, when used with mentally retarded children, the AD-HD diagnosis provided in DSM-III-R appears to be an improvement over DSM-III since the diagnosis is made using a combination of any 8 symptoms of inattention, impulsivity, and overactivity without emphasizing any particular category.

Children in both mentally retarded groups were rated higher in anxiety problems than normal IQ children. Children in the mentally retarded group in addition to children in the $A D-H D$ and mentally retarded $A D-H D$ groups were also rated higher on the Emotional/Overindulgent Factor than the normal IQ children. This suggests that mentally retarded children may have more anxiety problems than the norm. Any number of hypotheses could explain this finding. For instance, low intelligence could contribute to educational and social failure resulting in anxiety problems (McNally, 1991). Alternatively, there may be an autonomic nervous system defect that sets mentally retarded children at risk for anxiety problems. This area is full of possibilities for future research. 
An interesting finding was that the mentally retarded and mentally retarded $A D-H D$ children were viewed as less soclally disturbed than their AD-HD peers as reflected by scores on the Asocial Factor. This result may have implications for research in childhood depression, given the link to social skills problems (Lewinsohn, 1975). Depression in AD-HD children (Borden, Brown, Jenkins, 4 clingerman, 1987) and in mentally retarded children (Matson, 1982; 1984) are current areas of research. It has been suggested that poor peer relations may influence the development of social adjustment problems and depression in AD-HD children as they mature (Fee Matson, in press). However, the finding in this study that social acceptance difficulties were not significantly higher in mentally retarded $A D-H D$ children over mentally retarded children without AD-HD suggests that depression may be less of a risk for $A D-H D$ children who are concomitantly mentally retarded. Longitudinal study would help clarify this hypothesis.

The IOWA scales were found to be more conservative measures of $A D-H D$ and conduct problems than the Hyperactivity Index, replicating previous findings (Loney * Milich, 1982). However, it appears that the IOWA Scales may be even more conservative when used with mentally retarded children than when used with normal IQ children. Therefore, research employing a larger population of 
mentally retarded children is recommended for the development of norms and cut-off scores on the IOWA scales.

The CTRS as a measure of hyperactivity appears to contain appropriate items for use with mentally retarded children, since overall, a mentally retarded AD-HD group was distinguished from a non-AD-HD mentally retarded group. However, some guidelines for choosing a scoring system when assessing mentally retarded children were found. Since a large number of false positive mentally retarded subjects resulted with the Hyperactivity Index, based on the results of this study, it is not recommended for use with mentally retarded children. One-third of the mentally retarded non-AD-HD children in this study were above the cut-off on the Hyperactivity Index. This finding is probably due to items on the Hyperactivity Index describing aggressive and emotional behavior. This study was one of the first to examine the problem of $A D-H D$ among mentally retarded children. Results presented here provide considerable support for the existence of AD-HD among this population. However, further research is needed in order to replicate these findings and to develop norms so that standard AD-HD rating scales can be used for identifying mentally retarded children with AD-HD. Ultimately, methods for 
treating $A D-I: D$ in mentally retarded children will be further stimulated and evaluated. 


\section{SUMMARY}

The goal of this paper was to examine a particular behavior disorder, Attention Deficit-Hyperactivity Disorder, as it occurs in mentally retarded children. Using the CTRS-39 with four groups of boys, including normal control children, children with AD-HD, mentally retarded children, and mentally retarded children with ADHD, several interesting results were obtained.

There were no significant differences between the ADHD group and the mentally retarded AD-HD group on all but one of the Conners' Factors and no significant differences on the IOWA Conners' Scales that were extracted from the CTRS-39. Mentally retarded children in general were found to be more anxious than their normal peers, whereas AD-HD children were rated higher than the other groups on the Asocial factor. Attention problems were significantly correlated with conduct and hyperactivity factors for the normal IQ children but not for the mentally retarded children.

Therefore, we conclude that $A D-H D$ is essentially the same condition when 1 t occurs in children of normal intelligence and when it occurs in mentally retarded children. However, social deficits may be more problematic for normal IQ AD-HD children than for mentally retarded children with AD-HD. On the other hand, mentally retarded children appear to have greater difficulty with 
anxiety problems. Further, attention problems may be associated with mental retardation in general. 


\section{REFERENCES}

Abikoff, H. \& Gittleman, R. (1985). Classroom observation code: A modification of the Stony Brook Code. Peychopharmacology Bulletin, 21, 901-909.

Abikoff, H., Gittleman-klein, Klein, D. F. (1977). Validation of a claseroom observation code for hyperactive children. Journal of congulting and clintical Psychology, 5, 772-783.

Ablkoff, H. Gittleman, R. Klein, D. (1980). Classroom observation code for hyperactive children: A replication of validity. Journal of consulting and Clinical Poychology, 48, 55-565.

Alexandris, A., Lundell, F. W. (1968). Effect of thioridazine, amphetamine, and placebo on the hyperkinetic syndrome and cognitive area in mentally deficient children. Canadian Medical Association Journal ,98, 92-96.

Alvarez, U. L., \& Londono, J. P. C. (1982). Application of a DRo program with feedback for the modification of attention, distractibility and passivity in a retarded female adolescent. Pergpective en Paicologia, 1, 169-200.

Aman, M. G. (1982). stimulant drug effects in developmental disorders and hyperactivity: Toward a resolution of disparate findings. Journal of Autism and Developmental Dlsorders, 12, 385-398.

American Psychlatric Association (1968). Diagnostic and statistical manual of mental disorders (2nd ed.). Washington, D.C.: American Psychiatric Association.

American Psychiatric Association (1980). Diagnestic and statistical manual of mental disorders (3rd ed.). Washington, D.C.: American Psychiatric Association.

American Psychiatric Association (1987). Diagnostic and statistical manual of mental disorderg (3rd ed., rev.). Washington, D.C.: American Psychiatric Association. 
Anderson, J. C., Williams, S., HcGee, R., Silva, P. A. (1987). DSM-III disorders in preadolescent children. Prevalence in a large sample from the general population. Archives of General Psychiatry, 44, 69-76.

Anton, A. H. Greer, M. (1969). Dextroamphetamine, catecholamines, and behavior: The effect of dextroamphetamine in retarded children. Archlves of Neurology, 21, 248-252.

Atkins, M. S., Pelham, W. E., Licht, H. H. (1985). A comparison of objective classroom measures and teacher ratings of attention deficit disorder, Journal of Abnormal Child Psychology, 13, 155167.

August, G. J., \& stewart, M. A. (1984). Familial subtypes of childhood hyperactivity. Annual Progress in child Psychiatry and Child Development, 171, 364-377.

Barkley, R. A. (1982). Hyperactivity. In E. J. Mash \& L. G. Terdal (Eds.), Behayioral assessment of childhood disorders (pp. 127-184). New York: Gullford Press.

Barkley, R. A. (1985). The societal interactions of hyperactive children: Developmental changes, drug effects, and situational variation. In $R$. McMahon \& R. Peters (Eds.), Childhood disorders: Behavioral-developmental approaches (pp. 218243). New York: Brunner/Mazel.

Barkley, R. A. (1989). Attention deficit-hyperactivity disorder. In E. J. Mash \& R. A. Barkley. Treatment of childhoed disorders (39-72). New York: Guilford Press.

Bell, A., Zubeck, J. P. (1961). Effects of deanol on the intellectual performance of mental defectives. Canadian Journal of Psychology, 15, $172-175$.

Berry, C. A., Shaywitz, S. E., Shaywitz, B. A. (1985). Girls with attention deficit disorder: A silent minority: A report on behavioral and cognitive characteristics. Pediatrics, 76, 801-809. 
Blake, K. A. (1981). Educating exceptional pupile . Reading, Ma: Addison-Wesley Publishing Co.

Blunden, D. , Spring, C., Greenberg, L. M. (1974) . Validation of the Classroom Behavior Inventory. Journal of Consulting and clinical Peychology. 42, 84-88.

Borden, K. B., Brown, R. T., Jenkins, P., Clingerman, S. R. (1987). Achievement attribution and depressive symptoms in attention deficitdieordered and normal children. Journal of School Peychology, 25, 399-404.

Brigham, A. (1845). Third annual report of the New york State Lunatic Asylum, 59.

Brown, R. T. (1985). The validity of teacher ratings in differentiating between two subgroups of attention deficit disordered children with or without hyperactivity. Educational and Psychological Meagurement, 45, 661-669.

Brown, G. L., Ebert, M. H. \& Minichiello, M. D. (1985). Biochemical and pharmacological aspects of Attention Deficit Disorder. In L. M. Bloomingdale (Ed.), Attention Deficit Disorder: Identification. coures, and rationale. New York: Spectrum Publishing.

Buss, A. H., \&lomin, R. (1975). A temperament theory of personality development. New York: Wiley.

Campbel1, S. B. \& steinert, Y. (1978). Comparison of rating scale of child psychopathology in clinic and nonclinic samples. Journal of consulting and Clinical Psychology, 46, 358-359.

Cantwell, D. P. (1986). Attention deficit disorder in adolescents. Clinical Psychology Review, 6. 237-247.

Campbell, S. B., steinert, Y. (1978). Comparison of rating scales of child psychopathology in clinic and nonclinic samples. Journal of Consulting and Clinical Psychology, 46, 358-359.

Capera, P., Cote, R. \& Thivierge, J. (1985). Hyperactivity: Comment on Trite's article. Journal of Child Psychology and Psychiatry and Allied Disciplines, 26, 485-486. 
Chess, S. (1960). Diagnosis and treatment of the hyperactive child. New York state Journal of Medicine, 60, 2379-2385.

Chess, S., Fernandez, P. (1981). Do deaf children have a typical personality? Annual progress in child Pexchistry and child Development, 295-305.

Childers, A. T. (1935) Hyper-activity in children having behavior disorders. American Journal of orthopgychiatry, 5, 227-243.

Christensen, D. E. (1975). Effects of combining methylphenidate and a classroom token system in modifying hyperactive behavior. American Journal of Mental Deficiency, Bo, 266-276.

Clausen, J., Fineman, M., Henry, C. E., Whol, N. (1960). The effect of deanor (Z-Dimethylaminoethanol) on mentally retarded subjects. Training School Bulletin, 57, 3-12.

Conners, C. K. (1969). A teacher rating scale for use in drug studies with children. American Journal of Peychiatry, 126, 884-888.

Conners, C. K. (1970). Symptom patterns in hyperkinetic, neurotic, and normal children. Child peyelopment, 41, 667-682.

Conners, C. K. (1973). Rating scales for use in drug studies with children. Psychopharmacology Bulletin. Special Issue, NIMH.

Conners, C. K. (1976). Learning disabilities and stimulant drugs in children: Theoretical considerations. In R. Knights, \& D. J. Bakker (Eds.). The neuropsychology of learning disorders, (pp. 389-404). Baltimore: University Park Press.

Conners, C. K. (1989). Conners' Rating scales Manual. New York: Multi-Health systems, Inc.

Conners, C. K. , Rothschild, G., Eisenberg, L., Schwarz, L. S., Robinson, E. (1969). Dextroamphetamine sulfate in children with learning disorders. Archiyes of General Psychiatry, 21, 182-190. 
Cullinan, D., Epstein, M. H., Dembinski, R. J. (1979). Behavior problems of educationally handicapped and normal pupils. Journal of Abnormal Child Psychology, 7, 495-502.

Dalby, J. T. (1985). Taxonomic separation of attention deficit disorders and developmental reading disorders. Contemporary Educational Peycholggy, 10, $228-234$.

Davies, S. (1930). Social control of the mentally deficient.

Davis, K. V., Sprague, R. L., werry, J. S. (1969). stereotyped behavior activity level in severe retardates: The effect of drugs. American Journal of Mental Deficiency, 73, 721-727.

Dekrey, S. J., Ehly, S. W. (1981). Factor/cluster classification of profiles from the Personality Inventory for Children in a school setting. Psychological Reports, 48, 843-846.

Denson, R., Nanson, J. L., McWatters, M. A. (1975). Hyperkinesis and maternal smoking. Canadian Psychiateic Association Journal, 20, 183-187.

Dix, D. (1848). Memorial to the United states Congress 7 , 30th Congress, Firgt Session, Sen. Misc. No. 150 .

Douglas, V. I. (1972). Stop, look, and listen: The problem of sustained attention and impulse control in hyperactive and normal children. Canadian Journal of Behavioural Science, 4, 259282 .

Edelbrock, C. Greenbaum, R. , Conover, N. C. (1985). Reliability and concurrent relations between the teacher versions of the Child Behavior Profile and the Conners Revised Teacher Rating scale. Journal of Abnormal Child Psychology, 13, 295303 .

Eichsleder, W. (1985). Ten years of experience with 1,000 hyperactive children in a private practice. Pediatrics, 76, 176-184. 
Epstein, M. H., Nieminen, G. S. (1983). Reliability of the Conners Abbreviated Teacher Rating Scale across raters and across time: Use with learning disabled students. School Peychology Reyien, 12. 337-339.

Epstein, M. H., Cullinan, D., Gadow, K. D. (1986). Teacher ratings of hyperactivity in learningdisabled, emotionally disturbed, and mentaliy retarded children. Journal of Special

Education, 20, 219-220.

Fee, V. E., Matson, J. L. (1992). Past development and future trends. In J. L. Matson (Ed.), Handbook of hyperactivity. New York: Pergamon Press.

Fejes, K. D. , Prieto, A. G. (1987). The potential of relaxation training for the hyperkinetic trainable mentally retarded child. Child and Family Behayior Therapy, 9, 55-66.

Ferguson, H. B., \& Rapoport, J. L. (1983) . Nosological issues and biological validation. In M. Rutter (Ed.), Developmental neuropgychiatry. New York: Guilford Press.

Fernald (1919). State programs for the care of the mentally defective. Journal of PrychoAsthenics, 24, 119-120.

Fine, M. J. (1977). Hyperactivity: Where are we? In $M$. J. Fine (Ed.), Principles and techniques of intervention with hyperactive chlidren (pp.346). Springfield, Ill.: Thomas.

Fisher, W., Burd, L., Kuna, D. P., Berg, D. J. (1985). Attention deficit disorders and the hyperactivities in multiply disabled children. Behab12itation Literature, 46, 250-254.

Freedman, A. M. , Kaplan, H. I., Sadock, B. J. (1975). Comprehensive textbook of psychiatry II (Vol. 1), Baltimore: The Williams Wilkins Company.

Gadow, K. D. (1985). Prevalence and efficiency of stimulant drug use with mentally retarded children and youth. Pgychopharmacology Bulletin, 21, 291-303. 
Gadow, K. D. (1988). Attention deficit disorder and hyperactivity: Pharmacotherapy. In J. L. Matson (Ed.), Handbook of treatment aporoaches in child psychopathology. New York: Plenum Press.

Genovese, E., Napoli, P. A., Bolego-sonta, N. (1969). Self-aggressiveness. Life Sciences, B, 513-535.

Gillberg, I. C., G Gillberg, C. (1983). Three-year follow-up at age 10 of children with minor neurodevelopmental disorders: I. Behavioural problems. Developmental Medicine and child Neurology, 25, 438-449.

Glow, A. (1979). Cross-validity and normative data on the Conners' Parent and Teacher Rating Scales. In K. D. Gadow $\mathrm{J}$. Loney (Eds.). Paychosocial erpects of drug treatment for hyperactivity. Boulder, Co: AAAs Westview Press.

Goyette, C. H., Conners, C. K., Ulrich, R. F. (1978). Normal data on revised Conners Parent and Teachers Rating Scales. Journal of Abnormal Child Psychology, 6, 221-236.

Grossman, H. J. (Ed.) (1983). Clasgification in mental retardation. Washington, D.C.: American Association on Mental Deficiency.

Herr, S. S. (2983). Rights and adyocacy for retarded people. Lexington, MA: Lexington Books.

Hinshaw, S. P. (1987). On the distinction between attentional deficits/hyperactivity and conduct problems/aggression in child psychopathology. Psychological Bulletin, 101, 443-463.

Hogue, S. K., Biederman, J. (1986). A case of Tourette's syndrome with symptoms of attention deficit disorder treated with desipramine. Journal of clinical Psychiatry, 47, 478-479.

Holborow, P., Berry, P. (1985). Is there an independent syndrome of hyperactivity? A comment on Trites and Laprade. Journal of Child Poychology and Psychiatry and Allied Disciplines, 26, 487-489.

Homatidis, S. \& Konstantareas, M. M. (1981). Assessment of hyperactivity: Isolating measures of high discriminant ability. Journal of consulting and clinical Psychology, 49, 533-541. 
Jacob, R. G., O'Leary, K. D, Rosenblad, C. (1978). Formal and informal classroom settings: Effects on hyperactivity. Journal of Abnormal child Paychology, 6, 47-59.

Jacobsen, J. W. (1982). Problem behavior and psychiatric impairment within a developmentally disabied population I: Behavior frequency. Applied Research in Mental Retardation, 3, 121-139.

Kazdin, A. E. Esveldt-Dawson, K., Loar, L. L. (1983) . correspondence of teacher ratings and direct observations of classroom behavior of psychiatric inpatient children. Journal of Abnormal Child Psychology, 11, 549-564.

Kazdin, A. E., Matson, J. L., Senatore, V. (1983). Assessment of depression in mentally retarded adults. American Journal of Psychiatry, 140, 1040-1043.

Kelly, J. T., Koch, M., Buegel, D. (1976). Lithium carbonate in juvenile manic-depressive illness. Diseases of the Nervous Syetem, 37, 90-92.

Kessler, J. H. (1980). History of minimal brain dysfunctions. In H. E. Rie E. D. Rie, Handbook of minimal brain dysfunction: $A$ eritical review (pp. 18-51). New York: Wiley.

King, C. , Young, R. D. (1982). Attentional deficits with and without hyperactivity: Teacher and peer perceptions. Journal Abnormal Child Psychology, 10, 483-495.

Kuehne, C., Kehle, T., J., McMahon, W. (1987). Differences between children with Attention Deficit Disorder, children with Specific Learning Disabilities, and normal children. Journal of School Pgychology, 25, 161-166.

Lahey, B. B. , Piacentini, J. C., McBurnett, K., \& stone, P. (1988). Psychopathology in the parents of children with conduct disorder and hyperactivity. Journal of the American Academy of child and Adolescent Pgychiatry, 27, 163-170.

Levin, P. M. (1938). Restlessness in children. Archives of Neurology and Psychiatry, 39, 764770 . 
Lewinsohn, P. M. (1975). The behavioral study and treatment of depression. In $M$. Hersen, R. $M$. Eisler, C P. M. Miller (Eds.), Progrens in behavior modification, (pp. 19-55). New York: Academic Press.

Lipman, R. S., DiMascio, A. Riatig, N., Kirson, T. (1978). Psychotropic drugs and mentally retarded children. In $M$. A. Lipton, A. DiMascio, K. F. Killam (Eds.), Paychophermacology: A qeneration of progreas (pp. 1437-1449). New York: Raven Press.

Litrownik, A. J., White, K., McInnis, E. T. \& Licht, B. G. (1984). A process for designing selfmanagement programs for the developmentally disabled. Analygis and Intervention in Deyelopmental pisabilities, 4, 189-197.

Loney, J., Milich, R. (1982). Hyperactivity, inattention, and aggression in clinical practice. In $M$. Wolraich \& D. Routh (Eds.), Advances in developmental and behavioral pediatrics (Vol. 3, pp. 113-147). Greenwich, CT: JAI.

Luk, S. (1985). Direct observation studies of hyperactive behaviors. Journal of the American Acadeny of Child Peychiatry, 24, 338-344.

Matheny, A. P., G Dolan, A. B. (1980), A twin study of personality and temperament during middle childhood. Journal of Research in Personality. 14, 224-234.

Matson, J. L. (1981). Assessment and treatment of clinical problems in mentally retarded children, Journal of Applied Behavior Analysis, 14, 145152 .

Matson, J. L. (1982). The treatment of behavioral characteristics of depression in the mentally retarded. Behaviour Therapy, 13, 209-218.

Matson, J. L. (1983). Handbook of mental retardation. New York: Pergamon Press.

Matson, J. L. (1984). Behavioral treatment of psychosomatic complaints of mentally retarded adults. American Journal of Mental Deficiency, ⿱ㅗ, $638-646$. 
Matson, J. L., Barrett, R. P. (Eds.) (1982), Psychotherapy in the mentally retarded. New York: Grune stratton.

Matson, J. L., Epstein, M. H., Cullinan, D. (1984) . A factor analytic study of the Quay-Peterson scale with mentaliy retarded adolescents. Education and Training of the Mentally Ratarded, 19, 150154 .

Matson, J. L., Frame, C. L. (1985). Psychopathology in mentally retarded children and adelescents. Beverly Hills: Sage Publications.

Mayes, S. D. (1987). Assessment of preschool hyperactivity: Combining rating scale and objective observation measures. Topics in Early Childhood Special Education, 6, 49-61.

Mcconnel1, T. R., Cromwell, R. L., Bialer, I., G Son, C. D. (1964). studies in activity level: VII Effects of amphetamine drug administration on activity level of retarded children. American Journal of Mental Deficiency, 68, 647-651.

McGee, R., Williams, S. M., Silva, P. A. (1985). Factor structure and correlates of ratings of inattention, hyperactivity, and antisocial behavior in a large aample of 9-year-old children from the general population. Jourral of consulting and Clinical Psychology, 53, 480490 .

McNally, R. J. (1991). Anxiety and phobias. In J. L. Matson \& J. A. Mulick (Eds.), Handbook of mental retardation (2nd ed.), (Pp. 413-423). New York: Pergamon Press.

Milich, R., Loney, J., Roberts, M. A. (1986). Playroom observations of activity level and sustained attention: Two-year stability. Journal of consulting and clinical Psychology, 54, 272-274.

Morris, J. V., MacGillivary, R. C., Mathieson, C. M. (1955). The results of the experimental administration of amphetamine sulphate in oligophrenia. British Journal of Psychiatry, 101, 131-140. 
Morris, R. J., Collier, S. J. (1987). Assessment of Attention Deficit Disorder and Hyperactivity. In C. L. Frame J. L. Mateon (Eds.), Handbook of assessment in childhood poychopathology: Applied issues in diegnosis and treatment eyaluation (271-312). New York: Plenum Press.

Morrison, J. R., Stewart, M. A. 91974). Bilateral inheritance as evidence for polygenicity in the hyperactive child syndrome. The Journal of Nexvous and Mental Disease, 158, 226-228.

Nicholg, P. L., Chen, T. (1981). Minimal brain dysfunction: A prospective study. Hillsdale, NJ : Erlbaum.

offord, D. R. . Boyle, M. H., Szatmari, P., Rae-Grant, N. I., Links, P. S., Cadman, D. T., Byles, J . A. , Crawford, J. W., Blum, H. M., Byrne, C., Thomas, H., Woodward, C. A. (1987). Ontario Child Health study: II. Six-month prevalence of disorder and rates of service utilization. Archives of General Psychiatry, 44, 832-836.

O'Leary, K. D. Vivan, D. \& Nisi, A. (1985). Hyperactivity in Italy. Journal of Abnormal Child Psycholggy, 13, 3485-3500.

Paternite, C. E., Loney, J. (1980). Childhood hyperkinesis: Relationships between symptomatology and home environment. In $\mathrm{C}$. $\mathrm{K}$. Whalen \& B. Henker (Eds.), Hyperactive children: The social ecology of identification and treatment. New York: Academic Press.

Pauls, D. L., Shaywitz, S. E., Kramer, P. L., Shaywitz, B. A., Cohen, D. J. (1983). Demonstration of vertical transmission of attention deficit disorder. Annals of Neurology, 14, 363.

Payton, J. B., Burkhart, J. E., Hersen, M. \& Helsel, W. J.(1989). Treatment of ADDH in mentally retarded children: A preliminary study. Journal of the American Academy of Child and Adolescent Paychiatry, 761-767.

Pelham, w, E., Milich, R., Murphy, D. A., G Murphy, H. A. (198). Normative data on the IOWA Conners Teacher Rating scale. Journal of clinical Child Peychology, 18, 259-262. 
Peters, J. M. (1967) . Caffeine induced hemorrhagic automutilation. Archives Internationales de Pharmacodynamoie et de Tharapy, 169, 136-146.

Quay, H. C., * Peterson, D. R. (1975), Hanual for the Behavior Problem Checklist. Privately printed.

Quay, H. C., Routh, D. K. G Shapiro, S. K. (1987) . Psychopathology of childhood: From description to validation. Annual Review of Psychology, 38, 491-532.

Reeves, J. C., Werry, J. s., Elkind, G. S., zametkin, A. (1987). Attention deficit, conduct, oppositional, and anxiety disorders in childhood II: Clinical characteristics. Journal of the American Academy of Child and Adolescent Perchigtry, 26, 144-155.

Reiss, S., Levitan, G. W. , Szysko, J. (1982). Emotional disturbance and mental retardation: Diagnostic overshadowing. American Journal of Mental Deficiency, 86, 567-574.

Richardson, S. A., Katz, M., Koller, H., Mclaren, J., \& Rubenstein, B. (1979). Some characteristics of a population of mentally retarded young adults in a British city: A basis for estimating some service needs. Journal of Mentaly Deficiency Besearch, 23, 275-285.

Roberts, M. A. (1986). How is playroom behavior observation used in the diagnosis of attention disorder? Journal of children in contemporay society, 19, 65-74.

Routh, D. K. . Schroeder, C. S. (1976). standardized playroom measures as indices of hyperactivity. Journal of Abnormal Child Psychology, 4, 199-207.

Rutter, M. (1971). Psychiatric disorder and intellectual retardation in childhood. In $J$. Wortis (Ed.), Mental retardation: An annual review (Vol. 3, pp. 186-221). New York: Grune \& stratton.

Rutter, M., Tizard, J., Yule, W., Graham, P., \& Whitmore, K. (1976). Research report: Isle of wight studies, 1964-1974. Psychological Medicine, 6, 313-332. 
Safer, D. J. (1973). A familial factor in minimal brain dysfunction. Behavior Genetics, 3, 175-186.

Safer, D. J., Allen, R. P. (1976). Hyperactive children. Baltimore: University Park Press.

Sandoval, J. (1981). Format effects in two teacher rating scales of hyperactivity. Journal of Abnormal Child Paychology, 9, 203-218.

Sandoval, J., Lambert, N., Sassone, D. (1980). The identification and labeling of hyperactivity in children: An interactive model. In $C$. $K$. Whalen c B. Henker (Eds.), Hyperactive children: The social ecology of identification and treatment. New York.

Satin, M. S., Winsberg, B. G., Monetti, C. H., sverd, J., * Foss, D. A. (1985). A general population screen for attention deficit disorder with hyperactivity. Journal of the American Academy of Child Peychlatry, 24, 756-764.

Sattler, J. M. (1988). Assesement of children (3rd ed.). San Diego: Jerome M. Sattler.

Schachar, R., Rutter, M., Smith, A. (1981). The characteristics of situationally and pervasively hyperactive children: Implications for syndrome definition. Journal of Child. Psychology and Psychiatry, 22, 375-392.

Schaughency, E. A., Lahey, B. B. (1985). Mothers' and fathers' perceptions of child deviance: Roles of child behavior, parental depression, and marital satisfaction. Journal of consulting and Clinical Paychology, 53, 718-723.

Seguin, E. (1846). The moral treatment, hygiene, and education of idiots and other backward children. Paris: Balliere.

Shapiro, S. K., Garfinkel, B. D. (1986). The occurrence of behavior disorders in children: The interdependence of attention deficit disorder and conduct disorder. Journal of the American Acadeny of child Paychiatry, 25, 809-819. 
Shaywitz, S. E., Shaywitz, B. A., Cohen, D. J., \& Young, J. G. (1983). Monoaminergic mechanisms in hyperactivity. In M. Rutter (Ed.), Deyelopmental neuropeychlatry. New York: Guilford Press.

Spencer, D. A. (1970). Ronyl (pemoline) in overactive mentally subnormal children. British Journal of Paychiatry, 117, 239-240.

Sprague, R. L. \& sleator, E. K. (1973). Effects of psychopharmacologic agents in learning disorders. Pediatric clinice of North America, 20, 7191-735.

Stein, M. A., O'Donnell, J. P. (1985). Classification of children's behavior problems: Clinical and quantitative approaches. Journal of Abnormal Child Psychology, 13, 269-279.

stewart, M. A., Cummings, C., singer, S., deBlois, C. S. (1981). The overlap between hyperactive and unsocialized aggressive children. Journal of Chtld Paychology and Peychiatry, 22, 35-45.

St11l, G. F. (1902). Some abnormal psychical conditions in children. Lancet, 1, 1008-1012, 1077-1082, 1163-1168.

Tonick, I, Friehling, J., Warhit, J. (1973). Classroom observational code. Unpublished manuscript, Point of Woods Laboratory School, state University of New York at Stony Brook.

Torgersen, A. M., Kringlen, E. (1978). Genetic aspects of temperamental differences in infants: Their cause as shown through twin studies. Journal of the American Academy of Child Psychiatry, 17, 433-444.

Trites, R. L. (1979). Prevalence of hyperactivity in ottawa, Canada. In R. L. Trites (Ed.), Hyperactivity in children. Etiology, measurement, and treatment implications. Baltimore: University Park Press.

Ullmann, R. K. , Sleator, E. K., \& Sprague, R. L. (1985). A change of mind: Conners Abbreviated Teacher Rating scale reconsidered. Journat of Abnormal Child Psychology, 13, 553-566. 
Vincent, J. P., Williams, B. J., Harris, G. E., Jr., \& Duval, G. C. (1981). Classroom observation of hyperactive children: A multiple validation study. in K. D. Gadow $J$. Loney (Eds.), Peychosocial aspects of drug treatment for hyperactivity (Pp. 207-248). Boulder, co: Westview Press.

Walker, J. L. , Lahey, B. B., Hynd, G. W., G Frame, C. L. (1987). Comparison of specific patterns of antisocial behavior in children with conduct disorder with or without coexisting hyperactivity. Journal of consulting and clinical Peycholegy, 55, 910-913.

Wechsler, D. (1974) . Manual for the wechsler Intelligence Scale for children - Revised. San Antonio: The Psychological corporation.

Weiss, G. (1985). Hyperactivity: Overview and new directions. Psychiatric clinics of North America, $8,737-753$.

Welner, s., welner, A., stewart, M., Palkes, H., wish, E. (1977). A controlled study of siblings of hyperactive children. The Journal of Nervous and Mental Disease, 165, 110-117.

Wender, P. H. (1973). Hypothesis for a possible biochemical basis of minimal brain dysfunction. In R. M. Knights \& D. J. Bakker (Eds.), Neuropsychology of learning disorders: Theoretical approaches. Baltimore: University Park Press.

Werner, E. E., Bierman, J. M., French, F. E. (1971). The children of Kaual: A longitudinal study from the prenatal period to age ten. Honolulu: University Park Press of Hawail.

Werry, J. S. (1968). Studies of the hyperactive child IV: An empirical analysis of the minimal brain dysfunction syndrome. Archives of General Psychiatry, 19, 9-16.

Werry, J. S., G Sprague, R, L. (1970) . Hyperactivity. In C. G. Costello (Ed.), Symptoms of

Psychopathology (pp. 397-417). New York: Wiley. 
Werry, J. S., Hawthorne, D. (1976). Conners' teacher questionnaire-norms and validity. Australian and New Zealand Journal of Peychiatry, 10, 257262.

Werry, J. S. Elkind, G. S., E Reeves, J. C. (1987). Attention deficit, conduct, oppositional, anxiety disorders: III. Laboratory differences. Journal of Abnormal child Psychology, 15, 409428 .

Werry, J. S., Reeves, J. C. \& Elkind, G. S. (1987)/ Attention deficit, conduct, oppositional, and anxiety disorders in children. I: A review of research on differentiating characteristics. Journal of the American Academy of child and Adolescent Psychiatry, 26, 133-143.

Whalen, C. K. (1989). Attention Deficit and Hyperactivity Disorders. In T. H. Ollendick \& M. Hersen (Eds.), Handbook of child psychopathology. New York: Plenum Press.

Whalen, C. K., Collins, B. E., Henker, B., Alkus, S. R., Adams, D. \& stapp, J. (1978). Behavior observation systems of hyperactive children and methylphenidate (Ritalin) effects in systematically structured classroom environments: Now you see them, now you don't. Journal of Pediatric Psychology, 3, 177-187.

Whalen, C. K. , Henker, B. (1985). The social worlds of hyperactive (ADDH) children. Clinical Psychology Review, $\underline{5}, 447-448$.

Zametkin, A. J . \& Rapoport, J. L. (1986). The pathophysiology of attention deficit disorder with hyperactivity. A review. In B. B. Lahey 6 A. E. Kazdin (Eds.), Advances in clinical child paychology (Vol. 9). New York: Plenum Press.

aametkin, A. J., Karoum, F., Linnoila, M., Rapoport, J. L., Brown, G. L., Chuang, L. W. , wyatt, R. J. (1985). Stimulants, urinary catecholamines, and indoleamines in hyperactivity. A comparison of methylphenidate and dextroamphetamine. Archives of General Psychiatry, 42, 251-255 
Zigler, E., Balla, D., Hodapp, R. (1984). On the definition and classification of mental

retardation. American Journal of Mental

Deficiency, 89, 215-230. 


\section{APPENDIX A}

CONNERS FACTOR 1

83 


\title{
PLea8e MOTE
}

\begin{abstract}
Copyrighted materiale in thie document heve not been ftimed et the request of the euthor. They are avatiable for coneultetion, however. In the author'e univeretty 1 tbrary.
\end{abstract}
84
89
88
90
82
84
80
88
100 
APPENDIX B

CONNERS FACTOR 2 
APPENDIX C

CONNERS FACTOR 3

87 
APPENDIX D

CONNERS FACTOR 4 
APPENDIX E

CONNERS FACTOR 5

91 
APPENDIX F

CONNERS FACTOR 6

93 
APPENDIX G

CONNERS HYPERACTIVITY INDEX

95 


\section{APPENDIX H}

\section{IOWA CONNERS INATTENTION/OVERACTIVITY SUBSCALE}




\section{APPENDIX I}

IOWA CONNERS AGGRESSION/OPPOSITIONAL-DEFIANT SUBSCALE 
APPENDIX $\mathrm{J}$

CONSENT FORM

101 
Dear Parents,

I am a Doctoral student at L.S.U. asking for your help in completing my dissertation. I am working on a profect to better understand problems of childhood.

As a part of the project, you and your child's teacher would be asked to complete a few behavior checklists. We also ask for permission to briefly observe your child in school.

We hope that you will complete and return these forms to your child's teacher promptly. please understand that your child's name and any potentially identifying information will be kept strictly confidential and that information gained from the project may be potentially helpful to many children and their parents.

sincerely,

Virginia Fee, M.A. L.S.U. Doctoral student

Clinical Training
Johnny L. Matson, Ph.D. L.S.U. Professor of Psychology and Director of

$-$

I agree to my child's participation in this project but understand that I may revoke my permission at any time during the course of the study.

Child's Name

Parent's signature

Date 
APPENDIX $K$

DEMOGRAPHIC INFORMATION SHEET 
ID NUMBER:

Date of Birth Age

Sex: $M \quad F$

School

Teacher's Name

class placement

IQ Level

1. Has the child been ever been diagnosed as having Attention Deficit Hyperactivity Disorder?

circle: yes no

By whom? pediatrician psychologist psychiatrist school system other

When

2. Has the child ever been diagnosed as mentally retarded?

Circle: yes no

By whom? pediatrician psychologist psychiatrist school system other

When

3. Is the child currently taking any medication?

circle: yes no

Type

For 
APPENDIX L

BEHAVIOR CHECKLIST 


\section{PLeA8E Note}

Copyrighted materiale in this document have not been filmed at the request of the author. They are avatlable for coneultation, however, in the author' university library.

108

Univerefty Microfilim International 
APPENDIX $M$

OBSERVATION CODE 
Clessromm Observation Code Scoring Sheet

\begin{tabular}{|c|c|c|c|c|c|c|c|}
\hline I & 2 & 3 & 4 & 5 & 6 & $\boldsymbol{T}$ & 6 \\
\hline 1 & I & I & 1 & $\mathbf{I}$ & I & 1 & I \\
\hline 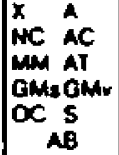 & $\begin{array}{ll}\mathrm{x} & \mathrm{A} \\
\mathrm{NC} & \mathrm{AC} \\
\mathrm{N} & \mathrm{AT} \\
\mathrm{OM} & \mathrm{OH} \\
\mathrm{OC} & \mathrm{s} \\
\mathrm{Ag}\end{array}$ & 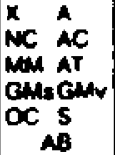 & $\begin{array}{ll}\mathrm{x} & \mathrm{A} \\
\mathrm{NC} & \mathrm{AC} \\
\mathrm{MN} & \mathrm{AT} \\
\mathrm{OM} & \mathrm{OHW} \\
\mathrm{OC} & \mathrm{S} \\
\mathrm{Ag}\end{array}$ & 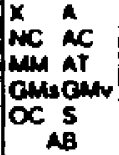 & 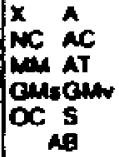 & 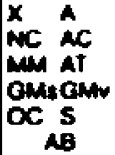 & $\begin{array}{ll} & A \\
N C & A C \\
M N & A T \\
G M & G M W \\
O C & 5 \\
A B\end{array}$ \\
\hline
\end{tabular}

\begin{tabular}{|c|c|c|c|c|c|c|c|}
\hline 1 & 2 & 3 & 4 & 5 & 6 & 7 & 0 \\
\hline 1 & I & I & I & I & 1 & I & 1 \\
\hline 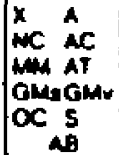 & $\begin{cases}x & A \\
M C & A C \\
M & A T \\
G H & G \omega h \\
O C & 5 \\
& \end{cases}$ & 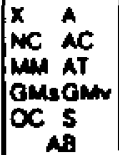 & 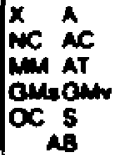 & 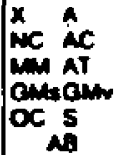 & 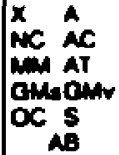 & 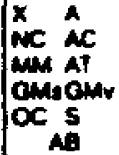 & 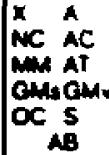 \\
\hline
\end{tabular}

\begin{tabular}{|c|c|c|c|c|c|c|c|}
\hline 1 & 2 & 3 & 4 & 5 & 6 & $\boldsymbol{T}$ & $\bullet$ \\
\hline I & I & I & I & I & 1 & I & 1 \\
\hline $\begin{array}{ll}x & A \\
M C & A C \\
M M & A T \\
G M S G M V \\
O C & 5 \\
& 9\end{array}$ & $\begin{array}{ll}\mathrm{K} & \mathrm{A} \\
\mathrm{MC} & \mathrm{AC} \\
\mathrm{MM} & \mathrm{AT} \\
\mathrm{GM} & \mathrm{GMN} \\
\mathrm{OC} & \mathrm{S} \\
\mathrm{AO}\end{array}$ & $\begin{array}{ll}x & A \\
M C & A C \\
M A & A T \\
L M s & O M W \\
O C & 5 \\
A B\end{array}$ & $\left|\begin{array}{ll}X & A \\
M C & A C \\
M A & A T \\
O M & G M r \\
O C & S \\
& A B\end{array}\right|$ & $\begin{array}{ll}x & A \\
M C & A C \\
M & A T \\
O M a g & \\
O C & 5 \\
A \theta\end{array}$ & 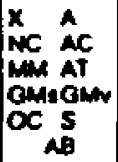 & 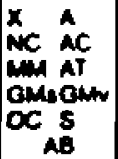 & 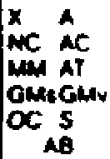 \\
\hline
\end{tabular}

\begin{tabular}{|c|c|c|c|c|c|c|c|}
\hline 1 & $?$ & 3 & 4 & 5 & 6 & 7 & $\theta$ \\
\hline 1 & I & 1 & I & 1 & $\mathbf{I}$ & I & 1 \\
\hline 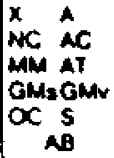 & 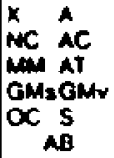 & $\begin{array}{ll}x & A \\
M C & A C \\
M M & A T \\
O M H G H & \\
O C & S \\
& A B\end{array}$ & $\begin{array}{ll}x & A \\
A C & A C \\
A M & A T \\
O M & O A W \\
O C & 5 \\
A B\end{array}$ & $\begin{array}{l}x \\
\mathrm{NC} A \mathrm{~A} \\
\mathrm{MAT} \\
\mathrm{OM} \mathrm{AMH} \\
\mathrm{CC} \mathrm{S} \\
\mathrm{AB}\end{array}$ & 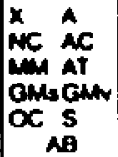 & 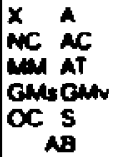 & $\begin{array}{ll}x & A \\
N C & A C \\
M & A T \\
O M A & G M \\
O C & S \\
A B\end{array}$ \\
\hline
\end{tabular}

Obarmer 
VITA

Virginia Elaine Fee was born on April 29, 1963 In Burlington, North Carolina. She earned her Bachelor's degree at Hamline University in 1985, and her Master's degree at Louisiana State University in 1988. Her research interests include mental retardation, autism, dual diagnosis, hyperactivity, and early intervention. She is currently an assistant professor at Mississippi State University. 


\section{DOCTORAL EXAMINATION AND DISSERTATION REPORT}

Candidate: VIrgInia Elalne Fee

Mojor Field: Paychology

Title of Disseration: Attention Defic1t-Hyperactivity Disorder Among Mentally Retarded Children

Approved:
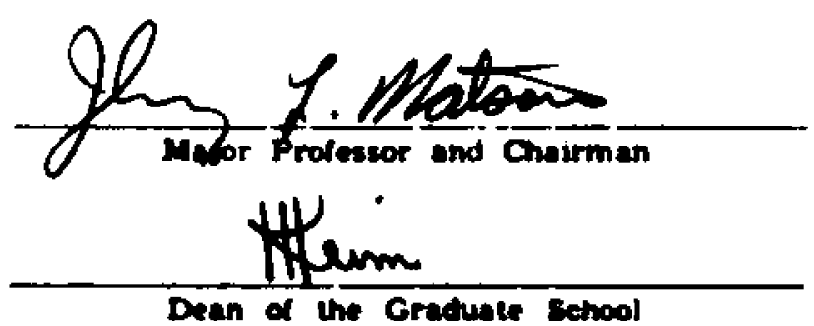

Dean of the Gractule Sehool
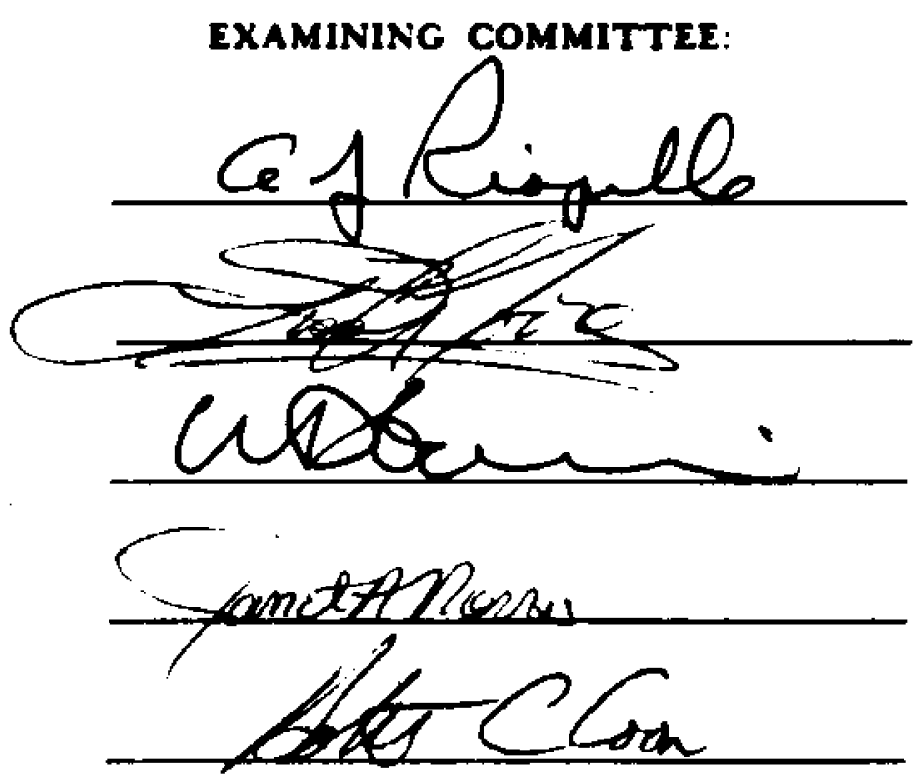

Date of Examination: 